NBER WORKING PAPER SERIES

\title{
FORCED MIGRATION AND HUMAN CAPITAL: EVIDENCE FROM POST-WWII POPULATION TRANSFERS
}

\author{
Sascha O. Becker \\ Irena Grosfeld \\ Pauline Grosjean \\ Nico Voigtländer \\ Ekaterina Zhuravskaya \\ Working Paper 24704 \\ http://www.nber.org/papers/w24704
}

\author{
NATIONAL BUREAU OF ECONOMIC RESEARCH \\ 1050 Massachusetts Avenue \\ Cambridge, MA 02138 \\ June 2018, Revised July 2019
}

\begin{abstract}
We received excellent comments at Boston University, the Chicago Booth Miniconference on Economic History, the NBER Political Economy Meeting, the Conference on 'Deep-Rooted Factors in Comparative Development' at Brown University, the 'Workshop in Political Economy and Economic Policy' at QMU London, the Oxford-Warwick-LSE (OWL) Workshop, the 'Culture, Institutions and Prosperity' conference in Paris, the Barcelona GSE Summer Forum, the International Conference of Europeanists in Madrid, and seminars at Barcelona GSE, Bristol, Cambridge, Chicago Harris, DIW Berlin, EALE Lyon, EEA-ESEM, Frankfurt, Harvard, PSE, Simon Fraser, UC Berkeley, UC Davis, UPF, Stanford, and Warwick. We thank Samuel Bazzi, Luis Candelaria, and Giampaolo Lecce for insightful discussions, Ilona Kawalec from CBOS for outstanding collaboration, and Vladimir Avetian for excellent research assistance. Sascha O. Becker acknowledges financial support by the ESRC Centre for Competitive Advantage in the Global Economy (grant no. ES/L011719/1). Ekaterina Zhuravskaya thanks the European Research Council (ERC) for funding from the European Union's Horizon 2020 Research and Innovation program (grant agreement No. 646662). The views expressed herein are those of the authors and do not necessarily reflect the views of the National Bureau of Economic Research.
\end{abstract}

NBER working papers are circulated for discussion and comment purposes. They have not been peer-reviewed or been subject to the review by the NBER Board of Directors that accompanies official NBER publications.

(C) 2018 by Sascha O. Becker, Irena Grosfeld, Pauline Grosjean, Nico Voigtländer, and Ekaterina Zhuravskaya. All rights reserved. Short sections of text, not to exceed two paragraphs, may be quoted without explicit permission provided that full credit, including ( $)$ notice, is given to the source. 
Forced Migration and Human Capital: Evidence from Post-WWII Population Transfers

Sascha O. Becker, Irena Grosfeld, Pauline Grosjean, Nico Voigtländer, and Ekaterina Zhuravskaya NBER Working Paper No. 24704

June 2018, Revised July 2019

JEL No. D74,I25,N33,N34

\section{ABSTRACT}

We exploit a unique historical setting to study the long-run effects of forced migration on investment in education. After World War II, the Polish borders were redrawn, resulting in largescale migration. Poles were forced to move from the Kresy territories in the East (taken over by the USSR) and were resettled mostly to the newly acquired Western Territories, from which Germans were expelled. We combine historical censuses with newly collected survey data to show that, while there were no pre-WWII differences in education, Poles with a family history of forced migration are significantly more educated today. Descendants of forced migrants have on average one extra year of schooling, driven by a higher propensity to finish secondary or higher education. This result holds when we restrict ancestral locations to a subsample around the Kresy border and include fixed effects for the destination of migrants. Since Kresy migrants were of the same ethnicity and religion as other Poles, we bypass confounding factors of other cases of forced migration. We show that labor market competition with natives and selection of migrants are also unlikely to drive our results. Survey evidence suggests that forced migration led to a shift in preferences, away from material possessions and towards investment in a mobile asset human capital. The effects persist over three generations.

Sascha O. Becker

Department of Economics

University of Warwick

Coventry CV4 8GL

United Kingdom

s.o.becker@warwick.ac.uk

Irena Grosfeld

Paris School of Economics

48 Bd Jourdan

Paris

France

irena.grosfeld@gmail.com

Pauline Grosjean

School of Economics

The University of New South Wales

Sydney NSW 2052 Australia

Australia

p.grosjean@unsw.edu.au
Nico Voigtländer

UCLA Anderson School of Management

110 Westwood Plaza

C513 Entrepreneurs Hall

Los Angeles, CA 90095

and NBER

nico.v@anderson.ucla.edu

Ekaterina Zhuravskaya

Paris School of Economics

48 Bd Jourdan

75014 Paris

France

ezhuravskaya@gmail.com 
"And so it happened that ... the marshall came: 'Leave' - 'But where should I go?'- 'To

Poland.' And I say: 'I am in Poland.' And he says: 'This is not Poland anymore.' "1

\section{Introduction}

Forced migration is a life-changing experience, leaving deep scars in the memory of expellees. Does the experience affect also subsequent generations? In his bestselling autobiographical novel, Amos $\mathrm{Oz}$ writes "It was always like that with Jewish families: they believed that education was an investment for the future, the only thing that no one can [...] take away from your children, even if, God forbid, there's another war, ... another migration” (p. 172; Oz, 2005). The idea that forced migration may affect preferences for education has been attributed by Stigler and Becker (1977) to Chicago economist Reuben Kessel. This argument has not only been made for Jews, but more generally - for example, in the academic literature by Brenner and Kiefer (1981): " $a$ group which had been compelled to emigrate from a country might take the portability of an asset into consideration when making an investment in a new country." However, this "uprootedness" hypothesis has proved hard to test. Even for the most prominent case - that of the Jews - Botticini and Eckstein (2012) have convincingly challenged the idea that expulsion and discrimination are the main drivers of their educational lead. ${ }^{2}$ It is notoriously difficult to identify the link between forced migration and investment in education. Forced migrants typically differ from locals along other socio-economic and cultural characteristics such as ethnicity, language, and religion. In addition, labor market competition with locals often affects educational choices of migrants.

In this paper, we explore a unique historical setting that allows us to study the effect of forced migration on human capital investment, absent the typical confounding factors. We study population transfers of millions of Poles in the aftermath of WWII when Polish frontiers were moved westward. Figure 1 illustrates the re-drawing of Poland's borders. The former Eastern Polish territories (Kresy) became part of the Soviet Union, while the former German areas - the Western Territories (WT) - became Polish. The latter had been home to about 8 million Germans before WWII, who had to resettle, leaving land and capital stock behind, with only about one million native Poles remaining there. In the East, Poles were forced to leave the Kresy territories, and the vast majority of them resettled in the largely emptied Western Territories. We can thus shed light on the long-run effects of uprootedness, by comparing the descendants of Poles who were forced to migrate with all other Poles - of the same ethnicity, language, and religion.

\footnotetext{
${ }^{1}$ Testimony cited in an exhibition of the Polish History Museum devoted to forced migrants from Kresy. See Appendix I for detail and sample photographs.

${ }^{2}$ They argue that Jewish preferences for education are explained by religious motives: Jewish boys were expected to read the Torah. These preferences trace back to the time of the fall of the second temple in Jerusalem (in $70 \mathrm{CE}$ ), before Jews started to be repeatedly expelled.
} 
We cooperated with the Polish social survey 'Diagnoza' to include questions about respondents' ancestors from Kresy in their 2015 wave. Among the almost 30,000 respondents, more than $11 \%$ had ancestors from Kresy. We find that descendants of forced migrants have significantly higher education today, as compared to all other Poles. The education advantage of descendants of forced migrants is quantitatively important: They have on average one extra year of schooling, driven by a higher propensity to finish secondary or higher education. Importantly, education levels of forced migrants were not higher before WWII. Figure 2 illustrates the reversal in the education of Poles from Kresy and their descendants: Before WWII, when Poland consisted of the Kresy territories and Central Poland (CP), Poles in the former had, if anything, lower literacy rates. In contrast, in today's Poland, people with ancestors from Kresy have substantially higher rates of secondary education. ${ }^{3}$ This receives further support when we examine the educational advantage of Kresy descendants by birth cohorts: Figure 3 shows that those forced migrants who had likely finished school by the time they were expelled from Kresy (i.e., the cohort born before 1930) do not differ from other Poles in terms of their education. For younger cohorts, we find a significant education advantage of Kresy descendants, even for those born two generations after their ancestors had been expelled. ${ }^{4}$

The Diagnoza Survey contains only information about ancestors from Kresy, but not about other ancestors. This may lead to recall bias if more educated respondents are more likely to remember the location of origin of their ancestors in general - and thus ancestors from Kresy in particular. To address this, we conducted an additional Ancestry Survey in 2016 in the Western Territories, where the majority of Kresy migrants were transported after WWII. We asked a representative sample of about 4,000 respondents about the origin location of all their ancestors (from the generation of youngest adults in 1939). We obtained the detailed location of almost 12,000 ancestors from all over Poland, as well as from Kresy. Using these data, we show that our results are not affected by recall bias. In addition, the Ancestry Survey allows us to compare the education levels of the descendants of forced migrants from Kresy, of voluntary migrants from Central Poland, and of Poles who had already lived in WT before the war (autochthons). We find that descendants of migrants from Kresy are the most educated, followed by descendants of voluntary migrants. Descendants of autochthons are the least educated group in Poland's Western Territories today.

The detailed ancestor locations reported in our Ancestry Survey also allow us to confirm our

\footnotetext{
${ }^{3}$ We use the share of people with a secondary degree in Figure 2 because it is comparable to literacy rates in 1921 in terms of its nationwide average. Among the respondents in our surveys, the rate of primary education is above $99 \%$, without any meaningful variation. In our empirical analysis, we use years of schooling as the main outcome variable.

${ }^{4}$ The results shown in Figure 3 use fixed effects for respondents' county of residence today. These absorb potential local differences in the education system and in the labor market environment.
} 
main results in a particularly restrictive border sample analysis. We restrict the sample to people whose ancestors in 1939 lived within less than 150 kilometers on either side of the Kresy border. At the same time, we include municipality fixed effects for the location of today's survey respondents. We find that among respondents who live in the same town or village today, those whose ancestors lived in Kresy, a few kilometers to the east of the Kresy border, have significantly higher education today than those whose ancestors lived in Central Poland, a few kilometers to the west of the Kresy border.

We examine two potential threats to identification: First, pre-existing differences - people from Kresy may have had higher education or different preferences for education already before WWII. Second, selection - people from either Kresy or from other parts of the country may have differentially selected into specific locations or occupations. We use a combination of historical data, survey data, and border discontinuity analyses to address these concerns. We then examine several possible mechanisms behind our results. Using both historical sources and empirical analysis, we document that Kresy migrants did not have differential access to resources, schooling, or employment opportunities at their destination locations. Their is also no indication that congested labor markets, differential fertility, out-migration, or economic conditions at destinations confound our results. We conclude that a shift in preferences towards investment in human capital is the most likely explanation for our findings. ${ }^{5}$

We support this interpretation by survey evidence, showing that descendants of forced migrants value material goods less, while having a stronger aspiration for education of their children. They also possess fewer physical assets, relative to the number of physical assets they can afford. Historical narratives from the time of expulsions corroborate our survey evidence, suggesting a change in preferences towards education. The Western Institute in Poznan (Instytut Zachodni) collected memoirs written by re-settlers in Western Territories in the 1950s, some of which were subsequently published and analyzed by historians. For example, the memoir by a forced migrant from Kresy, who came from a simple peasant family, reads: "In Western Territories, there was a specific situation. People did not attach great importance to material wealth. After all, nobody had it at that time ... most of the people who came here were still living in the memories of places of their origin and of material things that had belonged to their families for generations. In a new life situation, the cult of new values emerged, i.e., values that are indestructible, that cannot be lost, and that die with the man - the cult of knowledge, of skills, which can resist cataclysms" (Bieniasz (1987), as cited in Halicka (2015), p. 262). The former president of Poland (2010-15) Bronisław Komorowski emphasized in an interview how these values were passed on in families. "I was born

\footnotetext{
${ }^{5}$ At the end of the appendix, we provide a 'Guide to Identification and Mechanisms' with summary tables that schematize the corresponding evidence.
} 
near Wroctaw [the former German Breslau], in the house of grandparents Komorowski who had come there from Vilnius [in Kresy]... At home, nobody attached any importance to the material side, because everything that was valuable had been lost” (Gazeta Wyborcza, 3 June 2017).

Our interpretation is consistent with recent evidence pointing to how preferences can adjust to shocks to environmental or institutional conditions and persist in subsequent generations. A robust body of evidence has described how individual preferences change in response to exposure to violence, natural disasters, or economic shocks. ${ }^{6}$ Recent evidence suggests that these effects persist in future generations. ${ }^{7}$

Our work is related to a large literature that studies the economic effects of migration. This research typically focuses on two broad topics: the effect of migrants on short-run and long-run economic outcomes at their destinations, and socio-economic effects on migrants themselves and on their descendants. ${ }^{8}$ This literature studies both voluntary and forced migration. ${ }^{9}$ Key drivers of forced migration are natural disasters, international wars, and civil wars. ${ }^{10}$ Finally, a large body of work has examined the effects of voluntary migration, for instance in the context of the Age of Mass Migration to the US (Abramitzky, Boustan, and Eriksson, 2014; Sequeira, Nunn, and Qian, 2019). ${ }^{11}$

\footnotetext{
${ }^{6}$ See Blattman and Miguel (2010) for a review of the literature on exposure to violence, and Voors, Nillesen, Verwimp, Bulte, Lensink, and van Soest (2012), Bauer, Cassar, Chytilová, and Henrich (2014), Cassar, Grosjean, and Whitt (2013), or Jakiela and Ozier (2019) for more recent contributions. On natural disasters, see Cameron and Shah (2015), Cassar, Healy, and von Kessler (2017), and Hanaoka, Shigeoka, and Watanabe (2018). On economic shocks, c.f. Giuliano and Spilimbergo (2014), Fisman, Jakiela, and Kariv (2015), and Malmendier and Nagel (2016).

${ }^{7}$ Zhang (2018) documents systematic differences in preferences for competition among current Chinese high school students, depending on whether their grandparents or great-grandparents were exposed to state-imposed genderegalitarian policies in the 1950s. Going back many more generations, Galor and Özak (2016) document systematic variations in time preferences among present-day populations related to changes in agro-climatic conditions during the Columbian exchange, more than five centuries ago.

${ }^{8}$ See the comprehensive discussions in Borjas (2014), Card and Peri (2016) and Dustmann, Schönberg, and Stuhler (2016) for short-run effects; for evidence of the long-run effects of migrants at their destinations see Hornung (2014), Peters (2017), and Murard and Sakalli (2018). Dustmann, Frattini, and Lanzara (2012) provide an overview of the literature on second-generation immigrants. Katz and Rapoport (2005) build a model that formalizes how forced migration can lead to a shift away from investing in physical capital toward investing in human capital.

${ }^{9}$ The literature on the effects of forced migration is surveyed in Becker and Ferrara (2019). For example, Card (1990), Borjas and Monras (2017), Bharadwaj, Khwaja, and Mian (2015), and Braun and Omar Mahmoud (2014) use forced migration to identify the effect of migration on economic outcomes at the destination.

${ }^{10}$ Many papers examine relatively short-run effects of natural disasters. For instance, Sacerdote (2012) looks at the effects on test scores of students displaced from New Orleans after Hurricane Katrina. Nakamura, Sigurdsson, and Steinsson (2017) study the labour market outcomes of families displaced by the eruption of a volcano on an island off the coast of Iceland in 1973. Jacob (2004) and Chyn (2018) exploit exogenous variation in mobility caused by public housing demolitions in Chicago. While neither paper finds effects on educational attainment, displaced children have better labour market outcomes as adults.

${ }^{11}$ Bazzi, Gaduh, Rothenberg, and Wong (2016) study lottery-driven variation in voluntary migration during peace times in Indonesia to show that farmers are more productive in destination locations with agroclimatic endowments similar to where they come from.
} 
Our focus is on the long-term effects of forced migration after WWII, in the generations of children, grandchildren, and great-grandchildren of adult expellees. In the context of forced migration due to WWII, two related papers are Bauer, Braun, and Kvasnicka (2013) and Sarvimäki, Uusitalo, and Jäntti (2019). Bauer et al. (2013) study the economic integration of Germans expelled from Poland's Western Territories into West Germany. They find that migrant children tend to acquire more education than their native peers. The main mechanism behind this finding is congestion: Former farming families had to look for work outside agriculture because agricultural land in West Germany was already held by native Germans. We show below that this mechanism is unlikely to be at play in the largely emptied Western Territories. Sarvimäki et al. (2019) study the forced migration of $11 \%$ of the Finnish population after the Soviet invasion in 1939. Their focus is on income as the main variable of interest.

Relative to the existing literature, we make several contributions. First, we test the prominent hypothesis, untested by the previous literature, that uprootedness leads to human capital investment. Uprootedness is arguably a contributing factor to numerous studies on forced migration, such as Nakamura et al. (2017), Bauer et al. (2013), Sarvimäki et al. (2019). Thus, in terms of external validity our study has implications beyond the specific context of Poland. Second, we analyze the hitherto unstudied mass population movements in post-WWII Poland, where Poles expelled from Eastern Territories (Kresy) were resettled into the largely empty ex-German Western Territories. This unique setting allows us to bypass common confounding factors associated with forced migration, such as different ethnicity, language, or religion, as well as congested labor markets. Third, we break new ground by studying the long-run effects of forced migration on the descendants of migrants over several generations. This is of high policy relevance in a world with large waves of forced displacement. Finally, our results suggest that caution is warranted in the prominent approach that uses forced migration as an instrument to estimate the effect of voluntary migration - this instrument may have a direct effect on outcomes via a change in preferences.

The remainder of the paper is organized as follows. Section 2 provides historical background, Section 3 describes the data. Section 4 shows the main results using the two surveys. Section 5 examines threats to identification, such as (potential) selection of migrants, and 6 presents evidence on mechanisms. Section 7 concludes. 


\section{Historical Background}

\subsection{The Change of Poland's Borders}

Poland's Borders before 1945

Poland's borders have seen several changes over the last 500 years. The Polish Lithuanian Commonwealth (PLC) was established in 1569 when the Polish Kingdom and the Grand Duchy of Lithuania formed a union that lasted for over 200 years. In 1795, Poland lost its statehood as its territory was split among three European empires: Russia, Prussia, and Austro-Hungary. No sovereign Polish state existed until 1918; this period of Polish history is known as the 'Partitions of Poland.' At the end of World War I, the independent Polish state was recreated as the Second Polish Republic (SPR). Poland ceased to exist again as an independent state at the beginning of WWII, when Nazi Germany and the Soviet Union invaded the SPR in September 1939, splitting it according to the Molotov-Ribbentrop Pact.

\section{Poland's Borders after 1945}

At the end of World War II, an independent Poland reemerged within new borders that moved Poland 200 kilometers to the West. These new borders were established in accordance with the decisions taken during the Tehran, Yalta, and Potsdam Conferences. Poland gained the former German territories of Silesia, Pomerania and East Prussia, called by the communist propaganda "Recovered Territories" and later "Western Territories" (WT). At the same time, Poland lost the Eastern Borderlands, known as Kresy, located to the east of the Curzon line (more detail below). The Kresy territory was divided among the Soviet Republics of Lithuania, Belorussia, and Ukraine. Figure 1 illustrates the change in Polish borders. ${ }^{12}$

Henceforth, we refer to the part of Poland that belonged to the Second Polish Republic before WWII and continued to be Polish after WWII as 'Central Poland.' Thus, the territory of Poland before WWII was comprised of Central Poland and Kresy, whereas the Polish territory after WWII is comprised of Central Poland (CP) and WT. The 1931 Polish Census - the last census of the SPR counts about 3 million ethnic Poles in Kresy. Before WWII, according to the 1939 German census, 8.8 million people lived in areas that after WWII became the Polish Western Territories. Almost $90 \%$ of them declared to be 'German,' 10\% were Poles, and about 1\% Jews (Dziewanowski, 1977).

\footnotetext{
${ }^{12}$ The Eastern border of the Second Polish Republic was established at the signature of the peace treaty in Riga which marked the end of the Soviet-Polish war of 1919-1921. The borders of the Second Polish Republic around Silesia and East Prussia were adjusted as a result of several referenda in 1920-1922. Throughout the analysis and on the map, we consider the final SPR border as of 1922.
} 
Arbitrariness of the Kresy border of 1945

The Kresy border (i.e., the post-WWII Eastern border of Poland) was established roughly along the Curzon line after many discussions between Stalin and the Allies. The Curzon line, in turn, had been suggested as an armistice line in a note by British Foreign Secretary Lord Curzon during the 1920 Polish-Soviet conflict - a suggestion that was then disregarded by both Poland and the Soviet Union. The 1921 Treaty of Riga instead provided Poland with land that - on average - was about 250 kilometers eastward of the Curzon line. The Curzon line also did not correspond to the border between Germany and the Soviet Union according to the terms of the Molotov-Ribbentrop Pact of 1939; after the military defeat of Poland in September 1939, the Soviet Union annexed territories extending well to the west of the Curzon line - as far as Lublin and Warsaw. Nor did the Curzon line divide geographically diverse areas: There is no discontinuity in geo-climatic characteristics such as precipitation, temperature, elevation, terrain ruggedness, or in suitability for various crops (see Appendix V.1).

After recapturing Eastern Poland from Germany in 1944, the Soviets unilaterally declared the new border between Poland and the Soviet Union approximately along the Curzon line, to which the Allies ultimately conceded at the Yalta conference. ${ }^{13}$ Historians of Poland agree that the post-WWII border between Poland and the USSR, which we henceforth refer to as Kresy border, was arbitrary. For example, Davies (1981, p. 493) writes: "All decisions regarding the Polish frontiers were taken ad hoc[...] No attempt to trim the frontiers to the wishes of the population ever succeeded, [...] it was decided in 1944-5 to trim the population to the requirements of arbitrary frontiers."

\section{Poles in Kresy and Central Poland before WWII}

In the context of our study, a relevant question is whether Poles from Kresy were exposed to radically different experiences than Poles from other regions already before WWII. In the two periods when Poland was a sovereign state - PLC in 1569-1795 and SPR in 1918-39 - Poles had the same rights in all parts of the country. Namely, Poles who lived in what later became Kresy and Poles who lived in what later became Central Poland had exactly the same status (Davies, 1981). In contrast, during the Partitions of Poland, the living conditions and the rights of Poles differed across the three empires (e.g., Davies, 1981; Grosfeld and Zhuravskaya, 2015). The Russian and the Austro-Hungarian Partitions stretched over parts of Kresy and parts of Central Poland. Within

\footnotetext{
${ }^{13}$ In Appendix I.3 we give more detail on different variants of the Curzon Line that were under consideration. In Table A.12, we show that our results hold when we restrict our sample to counties that different versions of the Curzon line placed on different sides of the border, i.e., counties that could have become Polish or Soviet territories, depending on the different variants of the Curzon line.
} 
these two Partitions, Poles had the same rights irrespective of whether (or not) they lived in Kresy. ${ }^{14}$ Overall, Poles in Kresy faced differential discrimination (as compared to Poles in other parts of Poland) only once - when they were forced to move from Kresy at the end of WWII.

\subsection{Post-WWII Mass Population Movements}

As a result of the change of borders after WWII, mass population movements occurred. At the end of WWII, an estimated 2.5-3.4 million Germans (who had not fled as the Red Army advanced), and 1 million Poles were still located in the Western Territories (Dziewanowski, 1977). The remaining Germans were expelled from WT and had to resettle in Germany to the west of the Oder-Neisse line. Importantly, Polish and Soviet authorities had agreed on a mass population exchange following the change of the borders, according to which Poles from Kresy were forced to resettle within the new Poland, while Ukrainians, Belorussians, and Lithuanians had to leave Poland and resettle in the USSR. These mass movements of people began in 1944 and were largely completed by 1948 (e.g., Schechtman, 1962; Eberhardt, 2003).

The population exchange agreements were signed between the so-called Polish Committee of National Liberation - a puppet provisional government of Poland controlled by the Soviet Union and the governments of the three Soviet Republics of Ukraine, Belorussia, and Lithuania (Ciesielski, 1999). The official language of these agreements did not explicitly specify that the ethnic groups in question were to be expelled from the two respective sides of the Curzon line. However, historians agree that the members of these groups had no viable alternative but to move - this was also driven by the Polish and Soviet authorities seeking to quickly create irreversibility, by moving populations according to the new frontiers (c.f. Davies, 1981; Kersten, 1986).

\section{Forced migration from Kresy territories}

By 1950, 2.1 million Poles had been forced to move from the Kresy territories. The Polish State Repatriation Bureau tried to ensure an orderly movement of Poles from Kresy directly to WT. However, this was hard to implement because of the war-related devastation, destruction of infrastructure, and the lack of adequate transport. Approximately one quarter of Kresy migrants settled in Central Poland, many of whom had family ties there. The aim of the Polish authorities was to resettle Kresy deportees in those places in the Western Territories that had soil and climatic conditions most closely resembling the conditions at the origin locations, which in practice meant that trains brought people to the Western Territories from Kresy along the same latitude. Kresy Poles

\footnotetext{
${ }^{14}$ Below, in Section 6.2, we show that our results hold when we restrict the sample to ancestors who lived within the former Russian Partition of Poland (which covered about three quarters of the Kresy territory and one-half of the territory of Central Poland). The Prussian Partition did not include any part of Kresy, and the Austro-Hungarian Partition covered about one-quarter of Kresy (Grosfeld and Zhuravskaya, 2015). We also show that exposure to violence during WWII does not drive our results.
} 
had to leave most but not all of their possessions behind. Each family was allowed up to two tons of luggage.

Even though historians agree that Poles were forced to move from Kresy, not everybody left during the post-war population exchange. ${ }^{15}$ In 1945-1946, authorities in the Lithuanian and Belorussian SSR were concerned that agricultural production could be halted by a drop in agricultural labor and tried to prevent Poles in rural areas from leaving. In contrast, Ukrainian authorities did not attempt to prevent rural Poles from leaving due to the high levels of animosity between Poles and Ukrainians at the end of WWII (e.g., Ciesielski, 1999). In all three Soviet republics, pressure on the urban Polish population to leave was high. We exploit the urban vs. rural and Ukraine vs. rest-of-Kresy variation below.

\section{Voluntary migration from Central Poland}

Despite war-related destruction, land, housing, infrastructure, and capital stock were abundant after the expulsion of the German population from WT. Before the war, these territories had been densely populated. This made the Western Territories an attractive destination for voluntary migrants from Central Poland, who sought a better fortune than in their homeland: Deprivation and poverty were the main drivers of migration from Central Poland (Zaremba, 2012, p. 97). The flow of migrants from CP started as early as in the spring of 1945. Some of this early voluntary migration was spontaneous (mostly from the neighbouring Polish areas, sometimes on foot, or by horse carts and trucks), some was triggered by an advertising campaign organised by the Polish authorities that promoted a move to WT in order to populate the newly acquired land as quickly as possible. The campaign advertised the Western Territories as the land of abundant resources (see Figure A.3 in the appendix). As a result of this campaign, voluntary migrants came to WT from all over Central Poland, many of whom traveled long distances by train (Zaremba, 2012).

\section{Aggregate statistics on mass population movements}

The first full post-WWII population census in Poland of 1950 provides information on the mass population movements as of this date. In addition to statistics typically collected during censuses, it provides information about the mass movements of the Polish population by asking about the place

\footnotetext{
${ }^{15}$ The Socialist propaganda tried to suggest that "repatriates" returned voluntarily to their "mother country." As Ther (1996, p. 783) points out, the contrary was true. Kresy Poles regarded Eastern Poland as their mała ojczyzna (homeland). "These 'repatriates' did not return to their home country but were forcibly relocated to the former territories of a foreign country." Ther goes on to explain why the Socialist propaganda was convenient also for Western politics: "One possible explanation for the success of Eastern propaganda can perhaps best be described as 'bad conscience.' Since Winston Churchill and Franklin D. Roosevelt had agreed to the expulsion of the Eastern Poles without even consulting the Polish government, the West was prone to accept a rosy version of Polish postwar history.”
} 
of residence before September 1, 1939. ${ }^{16}$ Table 1 reports aggregate statistics from the 1950 census about the origin of the Polish population, separately in the Western Territories and in Central Poland. Of the total 24.6 million Polish population in 1950, 23\% (5.6m) lived in WT. Within the Western Territories, about 50\% (2.8m) came from Central Poland, 28\% (1.6m) came from Kresy, and 20\% (1.1m) were autochthons, i.e., Poles who had lived in WT when these territories belonged to Germany before the war. The remaining $2.7 \%$ came from other countries, mostly from France. Within Central Poland, 96.5\% (18.4m) of the population had CP origin and only 3\% (about $583,000)$ came from Kresy. Very few inhabitants of CP came from WT or from abroad $(0.1 \%$ and $0.3 \%$, respectively).

Importantly, post-WWII Poland was largely an ethnically and religiously homogeneous country, composed of ethnic Poles of Roman Catholic faith that differed only in their pre-WWII region of residence. The Western Territories, as the rest of Poland, were also ethnically and religiously homogenous: According to the 1950 census, $96 \%$ of WT's population were Poles, i.e., Roman Catholics and Polish native speakers. The rest of WT's population in 1950 were Jews, most of whom subsequently left (fewer than 300,000 Polish Jews survived WWII, and some had come to WT right after the war), and Ukrainians, who were forced migrants from CP to WT (during the so-called "Operation Vistula" - c.f. Snyder, 1999).

\section{The arrival of migrants to the Western Territories}

Upon arrival to Western Territories, Poles (irrespective of whether they came from Kresy or Central Poland) were allocated land, housing, and capital that expelled Germans had left behind. In rural areas, this primarily meant houses, land plots, and agricultural machines; in urban areas apartments, townhouses, shops, and office buildings. Initially, the Polish administration was very weak and operated under conditions of chaos, confusion, and lack of rules. There was no register of available properties, and people were more or less free to find and claim a place. During this first period, the capital goods left by Germans were distributed on a first come, first serve basis. "The Polish settlers were searching houses that were available and not reserved for other Poles... they were registering them with the local administration and-if there were no counter-arguments - could settle there" (Halicka, 2015, p. 203). When institutions and the Polish administration became stronger, authorities began to organize the distribution of land and capital. The arrival of migrants in WT coincided with the land reform in 1944-48. Migrants to rural areas typically got lots of 8-10 hectares per family; larger estates were parceled out among several families (Davies,

\footnotetext{
${ }^{16}$ In particular, respondents indicated if they had lived within the post-WWII Polish borders, and if so, in which region (voivodeship). If in 1939, respondents had lived outside the borders of post-WWII Poland, they had to indicate the country in which their 1939 place of living was located in 1950. Thus, forced Kresy migrants indicated that they lived in the USSR before the war.
} 
1981, p. 559). The peasants became owners of their land for an equivalent of a one-year harvest payable in several installments. Large farms of more than 100 hectares in WT (and more than 50 hectares in Central Poland) were transformed into State Agricultural Farms. After 1956, decollectivization reduced the number of collective farms but they remained important in WT. The houses and flats left by Germans were nationalized, and settlers got lifetime rental contracts.

Forced Kresy migrants and voluntary migrants from Central Poland arrived to the Western Territories at the same time. They were treated equally upon arrival because all migrants helped to achieve the main objective of the Polish authorities - to populate the Western Territories as quickly as possible (Schechtman, 1962, p. 213). As the deputy minister of Public Administration wrote to the Central Party Committee in May 1945: "The assessment of the organizational capacity of the Polish Nation abroad, and the security of our Western borders, will depend upon our capacity to populate and develop the area in the West" (cited in Halicka, 2015, p. 184). The Ministry of Recovered Territories collected statistics on the rates of arrival of migrants by month during 1946 and 1947. Figure A.6 in the appendix visualizes these data, showing that the share of migrant inflow from Kresy was about 40-50\% throughout this two-year window. By the end of 1947, the Kresy migration of the first repatriation wave came to an end. In Appendix VII.2 we discuss the so-called second repatriation of Poles from the USSR in 1955-1959, which amounted to about $10 \%$ of all Kresy migrants.

\subsection{Uncertainty Perceived by Kresy Migrants and its Connection with Education}

Historical and journalistic accounts of re-settlements into Western Territories suggest that forced migrants perceived a higher degree of uncertainty than other settlers or autochthons. The fate of the Western Territories was viewed as uncertain by its inhabitants because of the lack of a legal guarantee for the Polish-German border. ${ }^{17}$ The prominent Polish sociologist Zdzisław Mach describes this in an interview to the leading Polish newspaper Gazeta Wyborcza: "Settlers did not feel that the land they found was given to them forever. Until the 70s it was not certain that the Western Territories would remain part of Poland. ... Wtadysław Gomulka [the first Communist Party secretary] ...did not invest in the Western Territories because at heart he was not sure what would happen to them... It is not a random expression that the first generation of re-settlers were living on suitcases. They never felt sure and secure..." (Gazeta Wyborcza, Dec 29, 2010). Because of their traumatic experience of the previous expulsion, settlers from Kresy were particularly worried that Germany

\footnotetext{
${ }^{17}$ Until 1950, a mere memorandum of the Potsdam Conference guided the demarcation of the border along the Oder-Neisse line. In 1950, East Germany and socialist Poland signed the first bilateral treaty legalizing the OderNeisse line. In 1970, a similar treaty was signed between West Germany and Poland. The final treaty was signed by Poland and the unified Germany in 1990, and it was ratified by the Polish Sejm and the German Bundestag in 1991.
} 
would take over the Western Territories (see, e.g., Zaremba, 2012). ${ }^{18}$ Magdalena Grzebałkowska a journalist and author of "1945. War and Peace," a book based on testimonies of descendants of re-settlers to the Western Territories - was herself born in WT; her grandparents had been forced to move from Kresy. In her book, she reflects on her own experiences growing up: "As a child, I was worried that if something is postgerman, at some point it may become 'postpolish.' Unconsciously, I inherited the fear of my ancestors-settlers that the place where I live is given to us just for a moment" (Grzebałkowska, 2015, p.72). ${ }^{19}$ In an interview with the authors of this paper (conducted on May 9, 2018), Grzebałkowska confirmed that the experience of forced migration had an important effect on the perception of uncertainty, which in turn is related to education decisions: "Unlike migrants from Central Poland who always had an option of going back to Central Poland (and some actually did go back),... forced Kresy migrants got the 'one-way-ticket' and lost everything... when you lost everything, it seems worth investing in yourself, getting more education."

There were no systematic studies of educational attainment of re-settlers in the Western Territories by ancestors' origin before our paper. One important reason is that studies of forced migration from Kresy were prohibited in socialist Poland. Nevertheless, the scattered evidence that is available underlines the focus on education - even among the first generation of Kresy migrants. For example, the sociologist Irena Turnau assembled data on schooling in Wrocław (the former German Breslau) in 1948. She found that children of Kresy migrants were over-represented among secondary school students, and even more so among students in higher education. ${ }^{20}$

\section{Data}

We use numerous data sets for modern-day and historical Poland in our analysis. To capture modern-day educational attainment at the individual level, we use two surveys that also ask questions about the history of migration of respondents' ancestors in the aftermath of WWII. ${ }^{21}$ We complement these surveys with aggregate (regional and county-level) data from historical censuses that describe population characteristics in Poland before and after WWII. We describe each of these data sources in turn.

\footnotetext{
${ }^{18}$ A popular saying illustrates how Kresy migrants perceived the ambiguous status of the Polish borders before the 1970s: "One atomic bomb, and we will again return to Lviv... A second one... we will be back to Vilnius." (see, e.g., Zaremba, 2012).

19 "Postgerman" (poniemieckie) is an actual word in Polish, which refers specifically to land and assets in the Western Territories that were taken over by Poles from Germans after WWII.

${ }^{20}$ In Wrocław overall, $22 \%$ of the total population was born in Kresy. Among secondary school students, 27.5\% had roots in Kresy, and among students in higher education, 36.5\% came from Kresy (numbers reported in Turnau, 1960, pp. 31-33). These numbers have to be interpreted with caution because they combine different surveys.

${ }^{21}$ In Appendix IV.4, we use a third survey, the Life in Transition Survey (LiTS), which has a substantially smaller sample than the other surveys, but nevertheless confirms our results.
} 


\subsection{Diagnoza Survey}

The Diagnoza ('Social Diagnosis') survey is a large-scale household survey comparable to similar surveys in the US (PSID) or the UK ('Understanding Society'). It is a representative sample of the Polish population with 8 waves between 2000 and 2015. ${ }^{22}$ We commissioned the addition of several questions to the 2015 wave, which inquired whether any of the ancestors of the respondent came from Kresy and if so, from which exact location. ${ }^{23}$ The 2015 wave has almost 30,000 observations and allows us to compare education and other outcomes for respondents with any ancestors from Kresy to those without ancestors from Kresy. Our primary interest is investment in human capital. Thus, we focus on the education of respondents, using years of education as our main variable of interest. We also use two dummies for educational attainment: i) for having (at least) secondary education and ii) for (at least) completed higher (tertiary) education. We also use a number of questions about the attitudes of respondents toward the education of their children and toward the accumulation of material wealth. In addition, to measure the actual choices in accumulation of physical wealth, we construct a variable that measures the share of physical assets that respondents chose not to own, despite the fact that they could afford them.

A drawback of the Diagnoza Survey is that it only includes information on ancestors from Kresy, but not for ancestors from other areas, such as from Central Poland. In addition, Diagnoza does not report the exact ancestor who lived in Kresy (mother, father, grandmother, etc). Our Ancestry Survey fills these gaps.

\subsection{Ancestry Survey}

In 2016, we conducted our own survey in the Western Territories, which had seen the largest inflow of Kresy migrants after WWII. We asked a professional survey company to draw a representative sample of the population in the Western Territories (3,169 respondents), as well as an additional representative sample of people in WT with Kresy origin (900 respondents). ${ }^{24}$ We asked detailed questions about the place of living of respondents' ancestors for each ancestor in the generation of the youngest adults in 1939 (see Appendix IV.5). For instance, if the youngest adult generation was the respondent's parents, we asked where the mother and the father of the respondent lived

\footnotetext{
${ }^{22}$ For further detail on the survey see http://diagnoza.com/index-en.html (accessed on September 24, 2018).

${ }^{23}$ The main question was "Is there anybody in your household who himself or his parents or grandparents were living before WWII in the Eastern Borderlands (Kresy)?" If the answer was 'yes,' respondents were asked to indicate up to three localities where their relatives lived in Kresy in the summer of 1939. We geocoded these places.

${ }^{24}$ This oversample of 900 additional respondents with Kresy origin was done via 'random route' sampling, i.e., after interviewers had interviewed one of the randomly drawn 3,169 respondents, they would go from door to door in the neighbourhood until they found a respondent with Kresy origins. Our baseline regressions are unweighted, following the advice by Solon, Haider, and Wooldridge (2015) against the indiscriminate use of sample weights. However, our Ancestry Survey results are very similar when using weights that account for the oversampling of respondents with ancestors from Kresy (shown in Appendix IV.2).
} 
on September 1, 1939. If the generation of the youngest adults in the family in 1939 was the respondent's grandparents, we asked about the place of residence of each of the four grandparents. Similarly, if the generation of the youngest adults in 1939 was the respondent's great-grandparents, we solicited information about place of living for all eight great-grandparents. Overall, the 4,069 respondents gave information about 13,223 ancestors. The vast majority of respondents knew the exact name of the locality of origin of their ancestors (and not only the broad region of origin), even when the generation of youngest adults in the family was the great-grandparents. This highlights the importance of the mass population movements in the family histories of Poles. ${ }^{25}$ Overall, we were able to identify and geo-code the place of residence of 11,928 out of 13,223 ancestors.

We report summary statistics for the Diagnoza Survey and for our Ancestry Survey in Tables A.1 and A.2. Figure A.7 in the appendix displays the origin of ancestors in our Ancestry Survey.

\subsection{Historical Censuses}

Post-WWII Polish Census 1950 - The Polish Census in 1950 contains information on population movements. It asked in which Polish region or in which country people lived before WWII (according to post-WWII borders - thus, people who lived in Kresy in 1939 had to answer 'USSR'). In the Western Territories, this information is available by county (powiat) of residence; in Central Poland, it is available by region (voivodeship) of residence, and for Kresy there is no further detail (since all of Kresy falls under 'USSR').

Inter-War Polish Censuses: 1921 and 1931 - We use two censuses conducted in the Second Polish Republic. The census closest to WWII was conducted in 1931; it gives information on literacy rates and shares of population with different languages and religions by locality, but without cross-tabulations of the data. The 1921 Census, in contrast, has literacy rates by religious denomination, allowing us to measure the literacy rates among Roman Catholics. This is a close proxy for the literacy of ethnic Poles because in the SPR, only Poles were Roman Catholics; other groups had other religious affiliations, such as Orthodox Christians, Greek Catholics, and Jews.

Pre-WWI: Russian Empire Census 1897 - The 1897 Census of the Russian Empire (Troynitsky, 1899) provides information on literacy rates in the Russian language and in the native language for each native language in the empire. For our purposes, we extract the literacy of native Polish speakers in their native language.

Pre-WWI: German Empire Census 1900 - We use the share of Polish speakers in 1900 across localities in the Western Territories to proxy for the autochthon population.

\footnotetext{
${ }^{25}$ In our survey, we were able to monitor the interview process, and we were impressed by how survey respondents engaged with the questionnaire. Most respondents were fascinated by our questions about their ancestry to the extent that they made every effort to respond accurately. Many checked family archives to make sure that they gave the most precise answer possible. Some even called back to tell us their family stories.
} 


\subsection{Benchmarking Survey Data against Historical Census Data}

While we have no way to confirm the accuracy of ancestors' location provided by individual respondents, we can benchmark the survey responses against the information on post-WWII migration given by the 1950 Polish census. The latter provides both the pre-WWII location and the location in 1950; these two pieces of information can be used to construct migration movements in 1939-50. We compare these with population movements implied by the survey responses - i.e., the difference between respondent location in 2015/16 and the location of origin of their ancestors in 1939. We find that the ancestry information from the two surveys lines up well with the 1950 Census data - despite the fact that the former includes post-1950 movements, while the latter does not. Appendix III provides further detail and presents the graphs summarizing the data comparisons in Figures A.8 and A.9.

\section{Empirical Results: Forced Migration from Kresy and Education}

Our analysis relates modern-day education outcomes to the place of origin of respondents' ancestors. We use our two individual-level data sets - the Diagnoza Survey and our Ancestry Survey. The advantage of Diagnoza is that it covers all of today's Poland and has a large number of respondents. On the downside, Diagnoza only includes information on whether respondents had any ancestors from Kresy territories; it lacks information on how many ancestors were from Kresy, as well as the origin of ancestors from regions other than Kresy. Our Ancestry Survey fills this gap, by collecting information on all ancestors from the generation that was affected by the postWWII population transfers. One caveat is that the Ancestry Survey is run only in the Western Territories (where most Kresy migrants resettled). This potentially raises concerns about selection of voluntary migrants to WT. We discuss this in detail in Section 5. Overall, Diagnoza and our Ancestry Survey can be seen as complements: The former allows us to compare descendants of forced Kresy migrants to all other Poles, so that selection of the 'control group' is not an issue. The latter includes more detailed information on ancestors by focusing on the area that saw the largest inflow of migrants - Western Territories. The main results in both surveys are almost identical, suggesting that neither missing detail on non-Kresy ancestors in Diagnoza, nor selection of voluntary migrants in the Ancestry Survey confound our results.

In both surveys, we estimate the following regression at the respondent level $i$ :

$$
Y_{i}=\beta \text { Kresy }_{i}+\phi^{\prime} \mathbf{X}_{i}+\eta_{\text {Locality }_{(i)}}+\varepsilon_{i}
$$

where $Y_{i}$ denotes different outcomes of respondent $i$, such as measures of $i$ 's education and attitudes. In the Diagnoza Survey, Kresy $y_{i}$ is a dummy variable that takes on value one if any ancestor 
was from Kresy. When using our own Ancestry Survey, we can also compute Kresy $y_{i}$ as the share of $i$ 's ancestors from Kresy. $\mathbf{X}_{i}$ is a vector of the respondent's demographics: gender; age and age $^{2}$ interacted with birth-decade dummies; as well as indicators for whether the respondent lives in a rural area or in an urban county. ${ }^{26}$ Finally, $\eta_{\text {Locality }_{(i)}}$ represents fixed effects for the locality of respondents' residence. These absorb differences in the local socio-economic environment (such as labor market conditions) and also whether respondents live in the Western Territories. In particular, we use fixed effects for counties (powiat) or municipalities (gmina). There are 377 counties and 1,726 municipalities in the Diagnoza sample, and 115 counties and 407 municipalities in our Ancestry Survey. In Diagnoza, we cluster the error term $\varepsilon_{i}$ at the household level because several respondents may come from the same household in this survey. ${ }^{27}$

\subsection{Diagnoza Survey Results}

Using the Diagnoza Survey, Table 2 shows that individuals whose ancestors were expelled from Kresy territories have significantly higher levels of education today. Panel A presents our main results for the commonly used outcome variable 'years of education.' In columns 1 and 2 we examine the full sample, with approximately 28,300 respondents (out of whom more than 3,200 had Kresy ancestors). Column 1 reports results without any controls, showing that Kresy ancestry is associated with 0.97 additional years of schooling (relative to an average of 11.91 years). When we include county fixed effects and our set of baseline controls in column 2, the coefficient on Kresy ancestry remains similar and highly significant ( 0.82 extra years of schooling). This suggests that our results are not affected by spatial sorting of migrants, or by local characteristics such as labor markets or land quality. In what follows, we refer to column 2 (i.e., including county fixed effects) as our baseline specification. Column 3 shows that results are also very similar when we control for the particularly restrictive municipality fixed effects. Thus, even when comparing Poles who live in the same town or city today, those with Kresy ancestors have a substantial education advantage. This result also suggests that local unobservables do not confound our results. Next, columns 4 and 5 restrict the sample to respondents in rural and urban areas, respectively. The coefficient on Kresy is somewhat larger in urban areas (where the average educational attainment is also higher). In addition, the results are broadly similar for respondents in Central Poland and the Western Territories (columns 6 and 7). In other words, the descendants of forced migrants from Kresy enjoy an educational advantage everywhere in Poland.

\footnotetext{
${ }^{26}$ Note that by using the interactions of birth-decade dummies with age and with age ${ }^{2}$, we allow for non-linear effects of age within each age group.

${ }^{27}$ We exclude all respondents in Diagnoza who are younger than 16 years old - the age of completing secondary education. In our Ancestry Survey, all respondents are adults. All our results hold in more restrictive specifications that exclude respondents with 'student' status.
} 
In Panels B and C of Table 2 the dependent variable is an indicator for secondary and higher education, respectively. In our baseline specifications in column 2 we find that descendants of Kresy migrants are 11.2 percentage points more likely to finish secondary education (relative to a mean of $50 \%$ ), and 8.8 percentage points more likely to graduate from college (relative to a mean of $20 \%$ ). Thus, in relative terms, the association between Kresy origin and education is strongest for higher education. ${ }^{28}$

\section{Additional results in the Diagnoza Survey: Cohorts and labor market outcomes}

Figure 3 plots the coefficient on Kresy for different birth cohorts. We begin with the oldest cohort in the Diagnoza Survey - those born before 1930. If anything, Kresy migrants in the pre-1930 cohort have somewhat lower education than other Poles. This echoes the 1921 census data shown in Figure 2 above. The pre-1930 cohort was 16 or older in 1945 and thus would already have finished their secondary education (if they had any). In addition, within this cohort, respondents with Kresy ancestors are likely to be Kresy migrants themselves. Thus, the results for the oldest cohort in the Diagnoza Survey help us to address the concern that Kresy migrants may have had higher education already when they were displaced (either due to pre-existing differences or due to selection). Next, among the 1930 birth cohort (i.e., school-age children in 1945), respondents with Kresy origin have about 1.3 extra years of schooling. ${ }^{29}$ For later birth cohorts, the coefficient on Kresy declines somewhat but remains highly statistically significant. This makes sense in the context of our hypothesis that forced migration led to a shift in preferences towards education: The intergenerational transmission of preferences is not one-to-one, even when taking into account local peer effects and assortative mating of parents (c.f. Dohmen, Falk, Huffman, and Sunde, 2012). ${ }^{30}$ Table A.3 in the appendix presents regressions by birth cohorts and shows that results are

\footnotetext{
${ }^{28}$ To benchmark these estimates, we compare them to the effect of well-known interventions. In the US context, quasi-experimental evidence on federal financial aid by Dynarski (2003) shows that an additional \$2000 in aid increased college attendance by about eight percentage points. Bettinger, Long, Oreopoulos, and Sanbonmatsu (2012) find very similar effects of a "combined assistance and information treatment" for Federal Student Aid among lowincome families. High-school seniors whose parents received this treatment were eight percentage points more likely to attend and continue college over the subsequent three years. Our estimates for the Kresy effect are very similar in size.

${ }^{29}$ Historical accounts suggests that the supply of schools was well organized as early as 1946, even in the Western Territories. There was a great effort to ensure good educational opportunities (free and obligatory for the primary schools). The first schools in WT were established relying on the initiative of individual teachers. Very quickly, however, the communist authorities created special institutions to develop a unified educational system in WT and in CP (Online PWN Encyclopedia, accessed 28 March 2018).

${ }^{30}$ Note that the coefficients cannot be directly compared because the mean differs across cohorts. Figure A.10 in the appendix reports coefficients where $\ln$ (years of education) is the dependent variable (i.e., semi-elasticities that can be directly compared across cohorts). The pattern is very similar to Figure 3. Note also that among the 1990s birth cohort, many respondents were still in school/university by the time of the Diagnoza Survey in 2015. In the last column in Figure 3 we exclude students. If, in contrast, we include students the coefficient on Kresy for the youngest cohort declines to $2.6 \%$ but remains statistically highly significant.
} 
similar for secondary and higher education.

In Table A.4 in the appendix we show that higher education due to forced migration translates into better labor market outcomes. We find that respondents with ancestors from Kresy earn higher income, are more likely to work in white-collar occupations and are less likely to be unemployed.

\subsection{Ancestry Survey Results}

We now turn to our Ancestry Survey, which has information on the origin of all ancestors in a respondent's family tree, for the generation of the youngest adults at the beginning of WWII. We use this information to compare the descendants of forced migrants from Kresy with descendants of voluntary migrants from Central Poland, and with autochthons. Compared to Diagnoza (which covered all of Poland), a limitation of the Ancestry Survey is that it only includes respondents who live in the Western Territories - where most migrants from Kresy were transferred to. This potentially raises concerns about selection of other people who voluntarily migrated to WT (i.e., the 'control group' in our regressions). We conduct various analyses to show that such selection is unlikely to confound our results. Before moving to these checks and the interpretation of our results in Section 6, we show that our main results also hold in the Ancestry Survey.

\section{Respondent-Level Analysis in the Ancestry Survey}

We use the detailed information on ancestor origins in our Ancestry Survey to compute, for each respondent, the share of ancestors from Kresy, as well as from Central Poland, autochthons from the Western Territories, and from abroad (see summary statistics in Table A.2). Columns 1 and 2 in Table 3 (Panel A) present the simplest specification in the Ancestry Survey, using a dummy for "any respondent from Kresy," thus replicating the specification from the Diagnoza Survey. The coefficients are very similar to the first two columns of Table 2. Next, column 3 uses the share of ancestors from Kresy as the main explanatory variable in equation (1). This coefficient reflects the change in education outcomes when moving from zero to one in the share of ancestors from Kresy. The magnitude is similar to the results in columns 1 and 2, where we used a dummy for any ancestor from Kresy. ${ }^{31}$ In column 3 we also control for the share of ancestors from WT (autochthons) and of Poles who lived abroad in 1939 as controls. Note that the share of ancestors from Central Poland is thus the reference group. In addition, we control for the share of each respondent's

\footnotetext{
${ }^{31}$ Note that in column 3 the comparison group is Poles with ancestors from Central Poland (since we control for the share of ancestors from WT and abroad), while in column 2, the comparison group is ancestors from all of Poland. When running the same specification as in column 2 (i.e., without controlling for other ancestor shares), the coefficient on share Kresy is 0.917 , which is almost identical to the indicator for any ancestor from Kresy in column 2 . We provide an explanation for the similarity of these coefficients in Appendix IV.2: We show that having a majority of ancestors from Kresy does not have a differential effect on descendants' education above and beyond having any ancestor from Kresy (Table A.6). This result suggests that Kresy ancestry is salient within families. That is, in families with mixed ancestor origins, those from Kresy may dominate the transmission of values related to education.
} 
ancestors who came from rural origin locations to capture possible differences between migrants from rural and urban areas. The negative coefficient on the share of ancestors from WT shows that autochthons have lower education levels as compared to the control group - descendants of migrants from Central Poland. Overall, the ranking of respondents in terms of education by the origin of ancestors from highest to lowest is thus: Kresy, Central Poland, Western Territories or forced migrants, voluntary migrants, autochthons. Column 4 shows that our results are very similar when we include fixed effects for municipalities (gminy), which are typically smaller than local labor markets. This suggests that local socio-economic characteristics do not confound our results. In columns 5 and 6 we find that our results are remarkably similar for rural and urban destinations of migrants - in line with the Diagnoza results from Table 2. Finally, columns 7 and 8 show that the share of Kresy ancestors is also significantly related to the probability of finishing secondary and higher education.

\section{Ancestor-Level Analysis in the Ancestry Survey}

In the analysis above, we used our Ancestry Survey at the respondent level. We now turn to the data at the ancestor level, where each ancestor $a$ of each respondent $i$ is a separate observation. This allows us to control for characteristics of individual ancestors, and to exploit the origin location of ancestors around the Kresy border. We estimate the following equation:

$$
Y_{i}=\gamma \operatorname{Kresy}_{a_{(i)}}+\psi^{\prime} \mathbf{A}_{a_{(i)}}+\varphi^{\prime} \mathbf{O}_{a_{(i)}}+\phi^{\prime} \mathbf{X}_{i}+\eta_{\text {Locality }_{(i)}}+\varepsilon_{a_{(i)}},
$$

where $Y_{i}$ is respondent $i$ 's education, as above, and Kresy $y_{(i)}$ indicates whether ancestor $a$ of respondent $i$ came from Kresy. In addition to all standard controls for respondents' demographics $\left(\mathbf{X}_{i}\right)$ and destination location fixed effects $\eta_{\text {Locality }_{(i)}}$, we control for ancestor characteristics $\mathbf{A}_{a_{(i)}}$ : dummies for whether ancestor $a$ is a parent, grandparent, or great-grandparent of respondent $i .^{32}$ $O_{a_{(i)}}$ denotes characteristics at the origin location of ancestor $a$, such as whether $a$ came from a rural area. We also include dummies indicating whether the ancestor was an autochthon or came from abroad, which leaves origin from Central Poland as the comparison group. We cluster error terms by respondents to account for the fact that all ancestry information for a given respondent comes from the same source, and that education of the respondent does not vary across ancestors. ${ }^{33}$ Panel B of Table 3 presents results at the ancestor level. Throughout, we find positive and

\footnotetext{
${ }^{32}$ Among all ancestors in our sample, $23 \%$ were the parents; $55 \%$ were the grandparents; and $22 \%$ were the greatgrandparents.

${ }^{33}$ It is important to note that, econometrically, respondent-level and ancestor-level regressions are not equivalent. In Appendix IV.3 we present Monte Carlo simulations comparing the results of ancestor-level and respondent-level regressions. First, we show that the point estimate of the parameter of interest in the ancestor-level regression, $\gamma$, is smaller than the point estimate of the parameter of interest in respondent-level regressions, $\beta$ from equation (1). The
} 
significant coefficients on the indicator for ancestors from Kresy.

\subsection{Identification: Kresy Border Samples}

So far, we have presented correlations between Kresy ancestry and education. The higher educational attainment of Kresy descendants could be driven by pre-existing differences in the Eastern territories. For example, attitudes towards education may have been different in Kresy vs. Central Poland before WWII - even if literacy rates were very similar (see Figure 2). In what follows, we exploit the discontinuity around the Kresy border to identify causal effects of forced migration. ${ }^{34}$

\section{Kresy Border Sample based on the Diagnoza Survey}

We begin with the Diagnoza Survey, restricting the sample to an area of less than $150 \mathrm{~km}$ on each side of the border between Kresy and Central Poland. This arguably provides a culturally more homogenous area. At the same time, we face a challenge in constructing this sample. Because people from Kresy were expelled, there are no Diagnoza respondents living on the Eastern side of the border today. We thus use information on the location of ancestors that is provided in Diagnoza to identify respondents with ancestors within less than $150 \mathrm{~km}$ to the east of the Kresy border. ${ }^{35}$ As for the area within $150 \mathrm{~km}$ to the west of the Kresy border (i.e., in today's Poland), we assume that respondents without Kresy ancestors who live there today have also family roots in the area. We discuss the limitations of this assumption below.

We first check whether there were pre-existing differences in education between the two sides of the Kresy border. The left panel of Figure 4 shows that this is not the case: Literacy among Poles (identified by their Roman Catholic religion in the 1921 census) was very similar to the east and west of the Kresy border. There is also no significant trend in distance on either side of the border. In contrast, the right panel of Figure 4 shows that there is a sharp discontinuity at the border, with today's education jumping by about one year. This confirms that Kresy descendants have substantially higher education levels, even among a subset of individuals with ancestors from locations close to the Kresy border. Table A.10 in the appendix complements Figure 4, presenting spatial RDD results for the Diagnoza border sample.

relationship between the two parameters depends on the correlation between indicator variables for Kresy origin of different ancestors of the same respondent. Second, we show that the level of significance in the respondent-level and the ancestor-level regressions is similar irrespective of the correlation among ancestor origins of the same respondent, as long as this correlation is positive (as is the case in our data). In other words, statistical inference in both types of regressions is the same.

${ }^{34}$ In Appendix V (Figures A.11 and A.12) we show that there are no jumps at the Kresy border in geo-climatic characteristics or agricultural suitability. This complements the historical discussion on the arbitrariness of the Kresy border in Section 2.1 .

${ }^{35}$ Whenever a respondent in Diagnoza gave the location of more than one Kresy ancestor (see footnote 23), we make a conservative choice - using the maximum distance to the Kresy border among all ancestors. 
The Diagnoza border sample analysis has an important shortcoming: Individuals with Kresy roots now largely live in the Western Territories, far away from the historical Kresy border. Our border analysis compares them to individuals who still live close to the Kresy border today (to its west). That is, we compare respondents who live far apart today, rather than within the same location. Correspondingly, the border analysis with Diagnoza data does not include respondent location fixed effects, since these would absorb the relevant variation. Next, we address this limitation, using the more detailed data from our Ancestry Survey.

Border Sample based on the Ancestry Survey

Our Ancestry Survey allows us to perform a particularly restrictive border sample analysis. The Ancestry Survey includes information on ancestors from both sides of the Kresy border (see Figure A.13 in the appendix). This enables us to compare people who live in the same town or village in WT today, but have ancestors from the different sides of the Kresy border.

Figure 5 illustrates the border effect for years of education. As above, we restrict the sample to people with ancestor origin within less than 150 kilometers of the Kresy border. However, in contrast to the Diagnoza analysis presented above, we include fixed effects for the current municipality of respondents in addition to our standard controls. When comparing people who live in the same municipality in the Western Territories today, those whose ancestors were expelled from just a few kilometers to the east of the Kresy border have significantly higher education than those whose ancestors lived a few kilometers to the west of the Kresy border. Table A.11 in the appendix provides the corresponding spatial RDD results as well as robustness checks.

A limitation of the border analysis in our Ancestry Survey is that migrants from the west of the Kresy border (i.e., from Central Poland) may have been selected. To address this concern, the two border analyses from Diagnoza and our Ancestry Survey serve as complements: They show that the descendants of forced migrants from the east of the Kresy border are more educated than both 'stayers' in the area west of the Kresy border (Figure 4) and 'movers,' i.e., the descendants of (voluntary) migrants who left this area (Figure 5). The magnitude of the Kresy coefficients is also very similar in both analyses (see Tables A.10 and A.11). Thus, in combination, the two border samples suggest that selection of voluntary migrants is unlikely to confound our results. Nevertheless, we further discuss the possibility of selected voluntary migrants in Section 5 below.

\section{Contested Border Sample based on Ancestry Survey}

We discussed in Section 2.1 that the Kresy border was arguably drawn at random, without taking local conditions into account. We address possible skepticism about this issue by exploiting the fact that the location of the Kresy border was debated, with seven different versions being discussed at the Tehran Conference in 1943. In Appendix V.4, we further restrict the border sample to areas 
that were contested during the negotiations about the Curzon line. In this analysis, we only use ancestors who lived in an area that could either have become part of Poland or of the Soviet Union, depending on the variant of the Curzon line. Even within this highly restrictive subsample we find a statistically significant effect, with Kresy ancestry implying 0.94 extra years of schooling.

\section{Threats to Identification: Pre-Existing Differences and Selection}

This section discusses potential threats to our identification of an effect of forced migration on education. We discuss pre-existing differences between Kresy vs. the rest of Poland as well as selection of migrants.

\subsection{Pre-Existing Differences?}

Could our results be driven by differences of Poles from Kresy before forced migration took place? Possible examples include pre-existing differences in education, in preferences for schooling, and in socio-economic or geographic characteristics. We show that these are unlikely to affect our findings.

Were Poles in Kresy territories already more educated before WWII?

An obvious concern is that Poles who were expelled from Kresy may already have been more educated before WWII. We have presented evidence that makes this unlikely. Figure 2 shows that in 1921, Roman Catholics (i.e., Poles) in Kresy had a literacy rate of 58.9\%, as compared to $65.4 \%$ in Central Poland. This pattern also holds when we differentiate between rural areas (Kresy: 55.4\%; CP: 63.2\%) and urban areas (Kresy: 73.6\%; CP: 74.1\%). Thus, if anything, Poles from Kresy were less educated on average before they were forced to migrate, compared to Poles

in the rest of the Second Polish Republic. This is also confirmed by our cohort analysis in Figure 3 (slightly lower education for Kresy origin in the pre-1930s birth cohort) and in the border sample in Figure 4 (left panel).

Did Poles in Kresy already have higher preferences for education before WWII?

Pre-existing differences in preferences for education are unlikely to drive our results. As discussed in Section 2.1, there were no differences in access to education in Kresy vs. CP before WWII (all belonged to Poland then), and there was also no discrimination of Poles in Kresy. Thus, if Poles from Kresy had had pre-existing preferences for education, these should have materialized in higher literacy rates before WWII. If anything, the contrary is true, as we have shown above. In addition, since the Kresy border was arbitrary (see Section 2.1 and Appendix V), it is unlikely that pre-existing cultural differences would jump at the border. Consequently, our border samples in Figures 4 and 5 help to address possible unobserved differences that may have affected education 
decisions. $^{36}$

\section{Socio-Economic and Geographic Characteristics}

To what extent do characteristics of migrants' origin locations affect the relationship between Kresy origin and education? To analyze this, we use our Ancestry Survey and augment specification (2) by adding a host of socio-economic and geographic controls (all measured at ancestor origin locations), as well as their interaction with the Kresy origin dummy. Specifically, using the 1931 Polish Census, we interact Kresy origin with the share of Roman Catholics, the shares of native Polish, Ukrainian, and Russian speakers, the literacy rate, and the urbanization rate. We also use the share of literate Roman Catholics from the Polish Census of 1921. Going beyond the population characteristics, we look at climate variables at the place of origin. A large share of the population was working in agriculture pre-1939. Thus, land suitability, temperature, the precipitation-evatranspiration ratio, and ruggedness were key features of the economic environment. Tables A.13 and A.14 in the appendix show that neither the variables in levels nor their interaction terms with Kresy origin are statistically significant. In addition, the coefficients (all based on standardized variables) are typically an order of magnitude smaller than the coefficient on Kresy origin, while the latter maintains its magnitude and significance from our baseline ancestor regressions in Panel B of Table 3. We interpret this as evidence that the effect of uprootedness is driven by forced migration itself, and not by specific circumstances at the place of origin. ${ }^{37}$

\section{Differential War Exposure or Victimization?}

Could differential WWII experience of ancestors from Kresy be an alternative explanation for our findings? Since there are no comparable administrative data from Polish or Soviet sources, we draw on survey data from the Life in Transition Survey (LiTS), which asked respondents in 2016 whether anybody in the respondent's family was killed or injured as a result of WWII. In Appendix VI.2 we show that while Kresy ancestors are more likely to have experienced injuries or death, a family history of victimization in WWII is not associated with education of descendants, and the coefficient on Kresy origin is not affected by controlling for WWII victimization.

\footnotetext{
${ }^{36}$ Another factor that potentially could confound our results is the difference in the way imperial powers treated Poles during the Partitions of Poland before 1918 (see Section 2.1). To address this, we use the historical fact that within the Partitions, Poles were treated equally no matter if they lived in Kresy or Central Poland. In Appendix VI.4, we replicate our main result in a sub-sample of respondents whose ancestors came from the Russian Partition (see odd columns in Panel B of Table A.17). The Russian Partition covered about three quarters of Kresy and one half of Central Poland.

${ }^{37}$ Among the interaction results, the following are worth highlighting: Columns 1-5 of Table A.13 show that our main result is not affected by the share of Poles (measured either as Roman Catholics or Polish speakers), Ukrainians, or Russians at the ancestors' origin locations. Moreover, the interaction between Kresy and each of these shares is small, negative, and insignificant. This suggests that Kresy being a multi-ethnicity area, or a possible animosity between Poles and other ethnicities, does not affect our results.
} 


\subsection{Selection of Migrants from Kresy?}

Could selection of forced migrants from Kresy drive our results? We discuss the possibilities of selection at the origin and selection into destinations.

\section{Were forced migrants from Kresy selected at the origin?}

Selection at the origin is highly unlikely among Kresy migrants, as it contradicts the historical narrative of large-scale efforts to expel Poles from Kresy. However, some historical sources do suggest that forced migration out of Kresy was not fully homogenous (see Section 2.2). In particular, the pressure on Poles to leave was lower in rural areas in the Belorussian and Lithuanian parts of Kresy. In Ukraine, in contrast, strong animosity between Poles and Ukrainians at the end of WWII led to an (almost) complete exodus of Poles from both urban and rural areas. In what follows, we explore this variation by first restricting the sample to urban areas in Kresy, and then to the Ukrainian part of Kresy (our Ancestry Survey provides the detailed location of origin for each ancestor, both in terms of rural vs. urban origin and the county of origin).

If selection of Poles from Kresy affects our results, the coefficient on Kresy origin should vary depending on how much scope for selection a given ancestor's region of origin offered. Table 4 tests whether this is the case using our main outcome variable - years of education. We create different subsamples depending on ancestors' locations of origin. Regressions are run at the ancestor level as outlined by equation (2). Column 1 replicates our main result using all Kresy ancestors (Table 3, Panel B, column 3): Descendants of Kresy migrants have significantly higher education today. In columns 2 and 3 we present results for ancestors from urban and rural origin locations, respectively. The point estimates are slightly higher for the urban origin sample than for the rural origin sample. In other words, our results are stronger for locations from which the expulsion of Poles was nearly universal. One potential concern is that the estimate in the urban origin sample (column 2) could be inflated if more educated urban migrants from Kresy were displaced to rural areas in WT - according to the 1921 Census, literacy rates among Roman Catholics in Kresy were $73.4 \%$ in urban areas and $55.4 \%$ in rural areas. If these (former) city dwellers passed on their taste for education, we would compare their well-educated descendants to the less educated rural population in WT. We address this possibility in column 4, restricting the sample to those cases in which both ancestors and descendants are from urban areas. The effect of Kresy is almost unchanged.

In columns 5-8 in Table 4 we restrict the sample to ancestors from the Ukrainian part of Kresy, where expulsions were universal. The coefficient in column 5 (for both urban and rural origin locations) is very similar to the one when using all Kresy regions (column 1). In addition, columns 6 and 7 show a similar pattern as columns 2 and 3: Coefficients are highly significant for both rural and urban ancestors, and they are somewhat larger in the urban origin subsample. Finally, results 
hold when restricting the subsample to ancestors from urban areas in Ukraine whose descendants also live in urban areas today (column 8). In sum, the results shown in Table 4 render it unlikely that selection of Kresy migrants at the origin drives our findings.

\section{Selection of forced Kresy migrants into destinations?}

Even if selection from origin locations in Kresy is unlikely, there may have been selection of Kresy migrants or their descendants into destinations. As Table 1 has shown, while the majority of Kresy migrants settled in the Western Territories, about one quarter moved to Central Poland. For example, if the most capable Kresy migrants moved to the Western Territories, our results within WT would be biased. In addressing this concern, we begin by noting that the results from Table 2 (columns 6 and 7) show that the coefficients on Kresy ancestry are, if anything, larger in CP than in WT. Next, we present an additional check: We restrict the Diagnoza sample to respondents with Kresy origin. Within this subsample, we can compare the level of education of those who live in $\mathrm{CP}$ (overall 1,268 respondents) with those who live in WT (1,930 respondents). Table A.16 in the appendix shows that respondents with Kresy origin are somewhat less educated in the Western Territories than in Central Poland. ${ }^{38}$ Overall, these results suggest that selection of Kresy migrants into different areas of Poland is not driving our results.

\subsection{Selection of Voluntary Migrants?}

In our results for Poland overall (i.e., using the Diagnoza Survey), selection of the control group (i.e., voluntary migrants) is not an issue - the control group comprises 'all other Poles.' However, our Ancestry Survey was conducted only in the Western Territories, which was not only the destination of forced migrants from Kresy, but also of voluntary migrants from Central Poland. This raises the potential issue of selection of voluntary migrants. In particular, our Ancestry Survey coefficients on Kresy origin would be biased upward if the control group of less educated individuals was more likely to migrate from CP to WT after WWII. We perform several analyses to show that this is unlikely to confound our findings. We differentiate between regional and individual selection of the control group, briefly presenting the methodology and results in the main text, supported by further detail and tables in the appendix.

\section{Regional selection of voluntary migrants from Central Poland to the Western Territories?}

We first examine the possibility of regional selection - migrants from Central Poland coming from areas with historically lower education. For each respondent in our Ancestry Survey, we know the place of origin of each of their ancestors; and from the historical censuses, we know the literacy

\footnotetext{
${ }^{38}$ The reason for this difference is probably more recent migration of highly skilled individuals with Kresy background to large urban centers such as Warsaw and Cracow in Central Poland. People with Kresy origin have a particularly high education advantage in these areas (see Table A.16).
} 
rates at the counties of their origin. This allows us to compare the historical literacy rates in the counties of origin of ancestors from Kresy and from Central Poland. We perform this exercise in Appendix VI.4 and find that Kresy ancestors came on average from counties with a 3 percentage point lower literacy rate (see results shown in Table A.17). Thus, Kresy ancestors actually came from counties with slightly lower pre-WWII literacy, confirming the aggregate pattern shown in Figure 2.

\section{Individual selection of voluntary migrants from Central Poland to the Western Territories?}

While we have shown that regional (county-level) selection is unlikely to affect our results, individual selection of voluntary migrants remains a possibility. In particular, it could potentially be the case that uneducated Poles from Central Poland decided to seek a better fortune in the Western Territories, whereas educated Poles from the same origin counties stayed in Central Poland. Negative selection of Central Polish migrants into WT would imply that the control group in our Ancestry Survey has too low education, biasing the coefficient on Kresy origin upward. To examine directly whether there was negative individual selection, we would need historical individual-level data on the education of voluntary migrants and stayers in Central Poland. These are not available. However, we can check whether the (potential) selection concern matters for our results: If one were worried about negative selection of migrants from $\mathrm{CP}$, then this would be in the context of persistent lower education of their descendants today (i.e., of our control group). Building on this argument, we can use contemporaneous education to show that individual selection is unlikely to affect our results. In Table A.18 in Appendix VI.5 we show that respondents in WT with ancestors from Central Poland (i.e., voluntary migrants) are actually slightly more educated than a reasonable comparison group - today's respondents in those counties in $\mathrm{CP}$ where the voluntary migrants' ancestors originated from. In other words, descendants of voluntary migrants who live in WT today are somewhat more educated than their 'cousins' whose (grand)parents stayed in CP. Thus, if anything, our Ancestry Survey results tend to underestimate the effect for Kresy origin in WT. Overall, we find no indication that pre-existing differences or selection of migrants drive our results.

\section{Mechanisms}

In this section, we discuss several potential mechanisms that may drive the education premium of descendants of forced migrants from Kresy. We begin by showing evidence in favor of the most likely mechanism - a shift in preferences towards investment in education as opposed to physical capital ('uprootedness hypothesis' for short). We then continue by discussing alternative possible

mechanisms such as congested labor markets, differential out-migration, fertility, recall bias, or 
returns to schooling. None of these appear to play an important role. The table at the end of the appendix summarizes our findings for each (potential) mechanism, with references to tables and sections in the text.

\subsection{Preferences for Education vs. Ownership of Physical Assets}

In Table 5, we examine attitudes toward education and material possessions. In the first two columns, we use a question from Diagnoza about respondents' aspiration for the education of their children. The outcome variable is an indicator that takes the value of one for respondents with the highest aspiration. ${ }^{39}$ People with Kresy ancestors score 8 percentage points higher, relative to a mean of 59\%. Remarkably, this result remains very similar even after we control for the respondent's own education (column 2). Namely, among people with the same years of schooling (who also live in the same county), those with Kresy ancestors have significantly stronger preferences for the education of their children. ${ }^{40}$

In columns 3-6 of Table 5 we examine answers to the question: "What is the main condition for success in life?" We construct dummies for two categories: "possession of material goods" and "freedom." 41 Columns 3 and 4 show that respondents with Kresy ancestors are significantly less likely to believe that material goods determine a successful life; and columns 5 and 6 show that descendants of Kresy migrants value freedom more than the rest of the Polish population. In columns 7 and 8, we explore whether the lower value placed on material wealth among descendants of Kresy migrants translates into actual choices about accumulating assets. Diagnoza asks about the possession of 20 different assets (e.g., house, apartment, vacation home, garden land plot, ebook reader, home theatre, boat, etc.). For those assets not possessed, respondents were asked if this was for financial reasons. The dependent variable in columns 7-8 is the number of assets not owned for non-financial reasons (i.e., assets that the household could afford, but chooses not to purchase), divided by the number of all non-possessed assets. ${ }^{42}$ Consistent with the results on

\footnotetext{
${ }^{39}$ The survey question was: 'What level of education would you like your children to attain?' The answer included five categories, and we create a dummy for the highest category. Results are robust to using the full categorical variable instead of the dummy for the highest score. Note that the sample is smaller because this question is not answered when children have already finished their education.

${ }^{40}$ We elaborate on this finding by performing a Sobel-Goodman mediation test. This analysis (not reported in the table) examines the extent to which a mediating variable (respondents' own education) carries the influence of an explanatory variable (Kresy ancestors) to a dependent variable (aspiration for education of children). We find that only $16 \%$ of the effect of Kresy ancestry on "high aspiration" are mediated by own education. The remaining $84 \%$ constitute a "direct effect," i.e., independent of a respondent's own education. This finding suggests that our results are predominantly driven by a change in preferences towards education among people with Kresy ancestors, as opposed to a mechanism whereby educated parents have educated children.

${ }^{41}$ For each category, the dummy indicates the answers: "definitely yes," "yes," or "rather yes." The dummy equals zero for the answers "neither yes nor no," "rather no," "no," and "definitely no."

${ }^{42}$ Note that, unsurprisingly, Kresy migrants on average own a larger number of assets, as they earn higher incomes due to their higher levels of education. Controlling for the overall number of assets owned by each household does not
} 
stated preferences from columns 3 and 4, we find that Kresy migrants own fewer assets, relative to what they could afford. In sum, the results in Table 5 lend support to the interpretation that forced migration shifted preferences towards investment in education, and away from material possessions. $^{43}$

\subsection{Other Potential Channels}

In what follows, we examine whether our findings may be affected by different local characteristics or different behavior of Kresy migrants after migrants arrived at their destinations. Appendix VII.2 provides additional detail.

\section{Congestion}

The previous literature (as discussed in the introduction) showed that migrants who lack access to local land resources (which are held by entrenched locals) often opt for education in order to get access to non-agricultural jobs. This is unlikely to affect our results for several reasons. First, the Western Territories were largely empty after WWII, and the idea of the resettlement was to populate this 'empty space.' Second, as we described in Section 2.2, migrants from Kresy and CP arrived to WT at the same time (see Figure A.6 in the appendix). Third, if local congestion drove up the incentives to invest in education, this would be captured by county or municipality fixed effects. Thus, a differential congestion effect for Kresy and CP migrants is a priori unlikely.

While destination fixed effects in our previous regressions capture any direct effect of congestion on education, it is still possible that congestion affected Kresy migrants differentially. We test for this channel by using interactions between Kresy ancestry and the population of autochthons in the respondent's county of residence. Autochthons were a minority in WT, but their share varied across localities. We use the share of autochthons in 1950 from the Polish Census. ${ }^{44}$

Column 1 in Table 6 reports the results using data from Diagnoza, adding an interaction term between the Kresy origin of respondents and the county-level autochthon share to specification (1). We find that the interaction effect between Kresy origin and the historical presence of autochthons is relatively small and insignificant. To facilitate the interpretation of coefficient sizes, we standardized the share of autochthons. The interaction coefficient implies that a one standard

change our results.

${ }^{43}$ The shift in preferences in Table 5 could be founded on a number of underlying reasons: a shift in the subjective probability individuals attach to being forced to migrate in the future; an increase in the subjective probability that bad things may happen, so that education serves as insurance; a shift in the willingness to take risks; a shift in discount rates; and a shift in the valuation of education per se. We discuss those in Appendix VII.1.

${ }^{44}$ The share of autochthons in 1950 in the median county was 6.5\%, and the mean, 15\%. Figure A.15 in the appendix shows that this measure is highly correlated with the share of Polish speakers in 1900 in the German Empire Census. The share of autochthons shows ample variation, with some counties having more than $90 \%$ autochthons, while others had close to zero. 
deviation higher share of autochthons is only associated with 0.14 extra years of schooling among people with Kresy ancestors (relative to a direct Kresy coefficient of 0.73). These results suggest that differential congestion effects for Kresy migrants are unlikely to drive our findings.

\section{Returns to schooling}

Could our results be driven by differential returns to schooling for Kresy migrants? We shed light on this question in columns 2 and 3 in Table 6. We use log household income as dependent variable and are interested in the interaction term between Kresy origin and years of education. A significantly positive coefficient would imply higher returns to schooling for Kresy migrants. We find that the interaction term is small and insignificant in both the full Diagnoza sample and in the subsample of the Western Territories. ${ }^{45}$ This suggests that differential returns to schooling do not affect our results.

\section{Out-migration}

Columns 4 and 5 in Table 6 examine whether differential migration from Poland to other countries (after Poland's EU accession in 2004) may affect our results. For example, if uneducated people with Kresy origin (or educated people without Kresy origin) were more likely to leave Poland, then this could bias the coefficient on Kresy upwards. ${ }^{46}$ We use the fact that the Diagnoza Survey asked respondents whether they "plan to go abroad within the next two years, in order to work?" We find no relationship between Kresy ancestry and the intent to emigrate (column 4). The interaction term between education and Kresy origin is also small and insignificant (column 5). If the respondents who intend to emigrate have similar characteristics as those who had left already, these results make it unlikely that education and Kresy origin drove emigration in a fashion that would confound our results. As we do not observe directly the people who emigrated, we provide indirect evidence in support of this underlying assumption. The Polish Census in 2011 included a question: "How many members of your household have emigrated?" The response to this question is publicly available at the regional level. In Figure A.16 in the appendix we show that there is a strong positive relationship between the actual out-migration and the intent to emigrate reported in Diagnoza. This validates our use of the latter as a proxy for emigration from Poland.

\footnotetext{
${ }^{45}$ The coefficient on Kresy itself becomes smaller when we control for years of education, suggesting that the effect of Kresy origin on income works via education.

${ }^{46}$ However, emigration from Poland was very small before its accession to the EU. The share of people leaving Poland did not exceed $0.15 \%$ in any decade of the second half of the 20th century: 1951-1960: 0.14\%; 1961-1970: 0.07\%; 1971-1973: 0.06\%; 1975-1980: 0.07\%; 1981-1990: 0.07\%; 1991-1998: 0.06\% (numbers from Gawryszewski, 2005, pp. 472-473).
} 


\section{Differential fertility}

Columns 6 and 7 in Table 6 study the possibility that differential fertility may confound our results. For example, Kresy migrants may have chosen lower fertility to remain more flexible in an environment that they perceived as highly volatile (see Section 2.3). Fewer offspring could then have enabled higher investment in each child's human capital. Over time, this may have translated into stronger preferences for education. We find that Kresy origin is uncorrelated with the number of children per household member, which is the closest proxy for measuring fertility in our data. While this does not exclude the possibility that differential fertility played a role initially, it makes it unlikely that this channel is at play for the younger generations in our data. In addition, note that in the differential-fertility interpretation, preferences for education would develop later on, with lower fertility being the initial driver. In contrast, the historical evidence discussed in Section 2.3 suggests that preferences shifted immediately, as a direct result of uprootedness.

\section{Economic Development at Destination Locations}

The ex-German territories were more developed than Kresy before WWII. Could our results be driven simply by a move to a place with more developed infrastructure? Economic opportunities were open to both forced and voluntary migrants, so that they should be captured by location fixed effects. In addition, we observe a very similar Kresy effect among respondents in Central Poland, which was relatively poor (see Table 2, columns 6 and 7). This renders it unlikely that economic development at the destination confounds our results. Nevertheless, we provide further checks in Appendix VII.2, using three measures of economic development: 1) the density of railways in 1946 (at the county level), 2) log industrial production per capita in 1954 (at the regional level), and 3) the intensity of war-time destruction, separately in rural and urban areas in 1945 (at the county level). Using these measures, Table A.22 shows that while education is strongly associated with measures of development in WT on average, the effect of Kresy origin on education does not depend on the level of development - the interaction term in columns 2-5 is small and insignificant for all measures of economic development, with the exception of railway density (which is driven by one county: Warsaw). This makes it unlikely that economic conditions at the destination of migrants confound our results.

\section{Moving as Communities and Other Population Movements}

Another potential confounding factor is that Kresy migrants might be more likely to have moved in groups from the same location of origin. If moving in groups was beneficial to their descendants' education, this may have reinforced the education effect. While we do not have census-type data on the number of migrants in a destination who are from the same origin, our Ancestry Survey 
allows us to generate a proxy for migrants moving as whole communities (which we describe in Appendix VII.2). Table A.23 in the appendix shows that controlling for whether ancestors moved as a community does not affect our main results. On two other issues related to population movements, Table A.24 shows that our results are not affected i) by the share of Ukrainian and Belorussian minority groups that were expelled from Poland to the USSR in 1945-46 or ii) by the "second repatriation" of Poles from the USSR in 1955-59 (which made up only about 10\% of overall migration from Kresy).

Recall Bias: Missing Information About Ancestor Origin Locations

A potential worry in using survey data about ancestral origin is recall bias. For example, more educated respondents may have more information on the location of origin of their ancestors. This is a particularly important issue in the Diagnoza Survey, which only asks about Kresy origin. If education leads to a higher probability of remembering ancestors (and thus, ancestors from Kresy), then our results would be biased. In the Diagnoza Survey, we cannot control for this potential bias. In contrast, in our Ancestor Survey, recall bias is less of a concern, because it should affect both our 'treatment group' of Kresy ancestors as well as the 'control group' of ancestors from other areas. Furthermore, we can use our Ancestry Survey to check whether there is differential recall bias for people with ancestors from Kresy, i.e., whether remembering (any) ancestor location is correlated with Kresy origin. We construct, for each respondent, the share of ancestors with missing information on their location of origin (which is low - only $12 \%$ on average). We then show that i) the share of ancestors with missing information is uncorrelated with Kresy origin, and ii) controlling for this share does not affect our results. We describe how we built this variable in Appendix VII.2 and present the results in Table A.25.

\subsection{Summary of Mechanisms}

Summing up, we have performed numerous checks whose results speak against selection as a driver of our results and against alternative explanations such as differential returns on education and congestion of local labor markets. One explanation that is compatible with all our findings is the prominent - yet debated - argument that forced migration causes a shift in preferences towards investment in mobile assets, and especially in human capital. The population movements in Poland after WWII provide a unique setting to test this - notoriously hard-to-isolate - mechanism. Our results suggest that, indeed, forced migration caused an increase in educational investment among the affected Poles and their descendants, relative to all other Poles. Further, our findings suggest that this education premium is driven by a shift in preferences away from material possessions and towards education. 


\section{Conclusion}

Forced migration is an important issue in both historical and modern times. The UNHCR estimates that more than 65 million people are currently displaced from their home regions as a result of interstate wars, civil conflict, and natural disasters. While the immediate experience of expulsion is dramatic, the long-run effects on the displaced and their descendants are less clear. Such long-term effects of forced migration are difficult to distinguish from confounding factors. We collected novel individual-level data to study the long-run education effects of post-WWII population movements of Poles expelled from the Eastern Borderlands of Poland ('Kresy') that were taken over by the Soviet Union. We find that the children, grandchildren, and great-grandchildren of forced Kresy migrants have significantly higher average education levels than all other Poles. This result holds in border samples around the Kresy border and is robust to a host of controls. We also show that descendants of forced migrants value the education of their children more and assign a lower importance to material possessions. We examine several possible interpretations of these results and conclude that the most likely is that uprootedness shifted forced migrants' preferences away from investment in physical assets and toward investment in portable human capital.

We interpret this result as evidence for the classical 'uprootedness hypothesis.' We believe that uprootedness is an important mechanism in many contexts of forced migration, but often hard to isolate empirically. The Polish context is particularly well-suited to identify the uprootedness effect. The results by Nakamura et al. (2017) and Bauer et al. (2013) have a similar flavor, showing education effects of forced migration. However, in the context of these studies, it is not possible to separate the uprootedness mechanism from other explanations (such as congestion or lack of access to local assets, which the Polish context allows us to rule out).

The observed emphasis on education offers a glimmer of hope for descendants of those who experience expulsion. In view of large refugee flows in many parts of the world, a policy recommendation that emerges from our study is that governments in countries receiving forced migrants would be well advised to foster access to education to forced migrants and their children. While the international aid community does consider education as an important factor contributing to the reduction of economic and social marginalization of refugees (G20, 2017; UNICEF, 2017), our results show that the benefits of providing schooling for forced migrants may be even higher - and more persistent - than previously thought. 


\section{References}

Abramitzky, R., L. Boustan, and K. Eriksson (2014). A Nation of Immigrants: Assimilation and Economic Outcomes in the Age of Mass Migration. Journal of Political Economy 122(3), 467-506.

Bauer, M., A. Cassar, J. Chytilová, and J. Henrich (2014). War's Enduring Effects on the Development of Egalitarian Motivations and In-Group Biases. Psychological Science 25(1), 47-57.

Bauer, T. K., S. Braun, and M. Kvasnicka (2013). The Economic Integration of Forced Migrants: Evidence for Post-War Germany. The Economic Journal 123, 998-1024.

Bazzi, S., A. Gaduh, A. D. Rothenberg, and M. Wong (2016). Skill Transferability, Migration, and Development: Evidence from Population Resettlement in Indonesia. American Economic Review 106(9), 2658-2698.

Becker, S. O. and A. Ferrara (2019). Consequences of forced migration: A survey of recent findings. Labour Economics 59, 1-16.

Bettinger, E., B. Long, P. Oreopoulos, and L. Sanbonmatsu (2012). The Role of Application Assistance and Information in College Decisions: Results from the H\&R Block Fafsa Experiment. The Quarterly Journal of Economics 127(3), 1205-1242.

Bharadwaj, P., A. Khwaja, and A. Mian (2015). Population Exchange and its Impact on Literacy, Occupation and Gender - Evidence from the Partition of India. International Migration 53(4), 90-106.

Bieniasz, Z. (1987). Droga do mądrości. In Z. Linkowski (Ed.), Wiosna na Rumowisku i Inne Wspomnienia Pionierów. Gorzów Wielkopolski: Wydawnictwo regionalne.

Blattman, C. and E. Miguel (2010). Civil War. Journal of Economic Literature 48(1), 3-57.

Borjas, G. J. (2014). Immigration Economics. Cambridge, MA, USA: Harvard University Press.

Borjas, G. J. and J. Monras (2017). The Labour Market Consequences of Refugee Supply Shocks. Economic Policy 32(91), 361-413.

Botticini, M. and Z. Eckstein (2012). The Chosen Few: How Education Shaped Jewish History, 70-1492. Princeton University Press.

Braun, S. and T. Omar Mahmoud (2014). The Employment Effects of Immigration: Evidence from the Mass Arrival of German Expellees in Postwar Germany. Journal of Economic History 74(1), 69-108.

Brenner, R. and N. M. Kiefer (1981). The Economics of the Diaspora: Discrimination and Occupational Structure. Economic Development and Cultural Change 29(3), 517-534.

Cameron, L. and M. Shah (2015). Risk-Taking Behavior in the Wake of Natural Disasters. Journal of Human Resources 50(2), 484-515.

Card, D. (1990). The Impact of the Mariel Boatlift on the Miami Labor Market. ILR Review 43(2), 245-257.

Card, D. and G. Peri (2016). Immigration Economics by George J. Borjas: A Review Essay. Journal of Economic Literature 54(4), 1333-1349.

Cassar, A., P. Grosjean, and S. Whitt (2013). Legacies of Violence: Trust and Market Development. Journal of Economic Growth 18(3), 285-318.

Cassar, A., A. Healy, and C. von Kessler (2017). Trust, Risk, and Time Preferences After a Natural Disaster: Experimental Evidence from Thailand. World Development 94, 90-105.

Chyn, E. (2018). Moved to Opportunity: The Long-Run Effect of Public Housing Demolition on Labor 
Market Outcomes of Children. American Economic Review 108(10), 3028-3056.

Ciesielski, S. (1999). Przesiedlenie ludności polskiej z Kresów wschodnich 1944-1947. Warszawa: Wydawnictwo Neriton.

Davies, N. (1981). God's Playground. A History of Poland. Oxford: Oxford University Press.

Dohmen, T., A. Falk, D. Huffman, and U. Sunde (2012). The Intergenerational Transmission of Risk and Trust Attitudes. Review of Economic Studies 79(2), 645-677.

Dustmann, C., T. Frattini, and G. Lanzara (2012). Educational Achievement of Second Generation Immigrants: an International Comparison. Economic Policy 27(69), 143-185.

Dustmann, C., U. Schönberg, and J. Stuhler (2016). The Impact of Immigration: Why Do Studies Reach Such Different Results? Journal of Economic Perspectives 30(4), 31-56.

Dynarski, S. M. (2003). Does Aid Matter? Measuring the Effect of Student Aid on College Attendance and Completion. American Economic Review 93(1), 279-288.

Dziewanowski, M. K. (1977). Poland in the Twentieth Century. New York: Columbia University Press.

Eberhardt, P. (2003). Ethnic Groups and Population Changes in Twentieth Century Eastern Europe: History, Data and Analysis. London and New York: Routledge.

Fisman, R., P. Jakiela, and S. Kariv (2015). How did Distributional Preferences Change during the Great Recession? Journal of Public Economics 128(C), 84-95.

G20 (2017). Education and Skills Development in the Context of Forced Migration. Technical report, G20 Insights.

Galor, O. and O. Özak (2016). The Agricultural Origins of Time Preference. American Economic Review 106(10), 3064-3103.

Gawryszewski, A. (2005). Ludnosc Polski w XX wieku. Warszawa: IGIPZ PAN.

Giuliano, P. and A. Spilimbergo (2014). Growing up in a Recession. Review of Economic Studies 81(2), 787-817.

Grosfeld, I. and E. Zhuravskaya (2015). Cultural vs. Economic Legacies of Empires: Evidence from the Partition of Poland. Journal of Comparative Economics 43(1), 55-75.

Grzebałkowska, M. (2015). 1945. Wojna i pokój. Warszawa: Agora.

Halicka, B. (2015). Polski Dziki Zachód. Przymusowe Migracje i Kulturowe Oswajanie Nadodrza 19451948. Krakow: TAiWPN Universitas.

Hanaoka, C., H. Shigeoka, and Y. Watanabe (2018). Do Risk Preferences Change? Evidence from the Great East Japan Earthquake. American Economic Journal: Applied Economics 10(2), 298-330.

Hornung, E. (2014). Immigration and the Diffusion of Technology: The Huguenot Diaspora in Prussia. American Economic Review 104(1), 84-122.

Jacob, B. A. (2004). Public Housing, Housing Vouchers, and Student Achievement - Evidence from Public Housing Demolitions in Chicago. American Economic Review 94(1), 233-258.

Jakiela, P. and O. Ozier (2019). The Impact of Violence on Individual Risk Preferences: Evidence from a Natural Experiment. Review of Economics and Statistics 101(3), 547-559.

Katz, E. and H. Rapoport (2005). On human capital formation with exit options. Journal of Population Economics 18(2), 267-274. 
Kersten, K. (1986). Narodziny systemu wladzy. Polska 1943-1948. Paris: Wydawnictwo Libella.

Malmendier, U. and S. Nagel (2016). Learning from Inflation Experiences. Quarterly Journal of Economics 131(1), 53-87.

Murard, E. and S. Sakalli (2018). Mass Refugee Inflow and Long-run Prosperity: Lessons from the Greek Population Resettlement. Working Paper.

Nakamura, E., J. Sigurdsson, and J. Steinsson (2017). The Gift of Moving: Intergenerational Consequences of a Mobility Shock.

Oz, A. (2005). A Tale of Love and Darkness. Vintage, NY City.

Peters, M. (2017). Refugees and Local Agglomeration - Evidence from Germany's Post-War Population Expulsions.

Sacerdote, B. (2012). When the Saints Go Marching Out: Long-Term Outcomes for Student Evacuees from Hurricanes Katrina and Rita. American Economic Journal: Applied Economics 4(1), 109-135.

Sarvimäki, M., R. Uusitalo, and M. Jäntti (2019). Habit Formation and the Misallocation ofLabor: Evidence from Forced Migrations.

Schechtman, J. B. (1962). Postwar Population Transfers in Europe 1945-1955. Philadelphia: University of Pennsylvania Press.

Sequeira, S., N. Nunn, and N. Qian (2019). Migrants and the Making of America: The Short and Long-Run Effects of Immigration during the Age of Mass Migration. Review of Economic Studies forthcoming.

Snyder, T. (1999). To Resolve the Ukrainian Question once and for all: The Ethnic Cleansing of Ukrainians in Poland, 1943-1947. Journal of Cold War Studies 1(2), 86-120.

Solon, G., S. J. Haider, and J. Wooldridge (2015). What Are We Weighting For? Journal of Human Resources 50(2), 301-316.

Stigler, G. J. and G. S. Becker (1977). De Gustibus Non Est Disputandum. American Economic Review 67(2), 76-90.

Ther, P. (1996). The Integration of Expellees in Germany and Poland after World War II: A Historical Reassessment. Slavic Review 55(4), 779-805.

Troynitsky, N. (1899). The First Total Census of Russian Empire in 89 Volumes. The Central Statistical Bureau of the Ministry of Internal Affairs of the Russian Empire, St. Petersburg, 1899-1905.

Turnau, I. (1960). Studia nad strukturq ludnościowa polskiego Wroctawia. Poznań: Instytut Zachodni.

UNICEF (2017). Education Uprooted: For Every Migrant, Refugee and Displaced Child, Education. Technical report, UNICEF.

Voors, M., E. Nillesen, P. Verwimp, E. Bulte, R. Lensink, and D. van Soest (2012). Violent Conflict and Behavior: A Field Experiment in Burundi. American Economic Review 102(2), 941-964.

Zaremba, M. (2012). Wielka Trwoga. Polska 1944-1947. Kraków: Wydawnictwo Znak.

Zhang, J. (2018). Culture, Institutions, and the Gender Gap in Competitive Inclination: Evidence from The Communist Experiment in China. Economic Journal Forthcoming. 


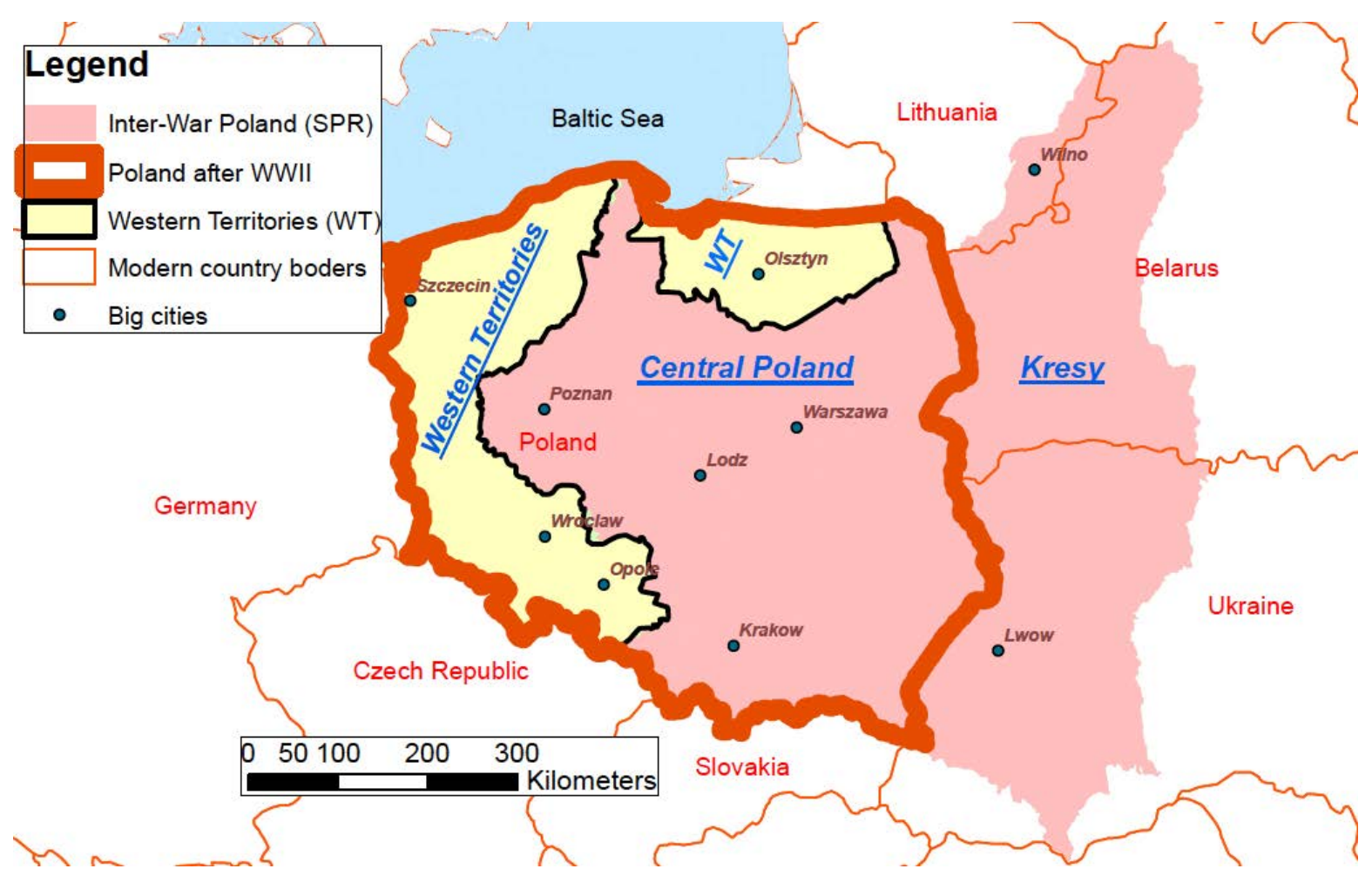

Figure 1: Map of Poland's Territorial Change after WWII

Note: The figure illustrates the re-drawing of Poland's borders after WWII. The former Eastern Polish territories (Kresy) became part of the Soviet Union, while the former German areas in the West and North (Western Territories) became Polish. Poles from Kresy were forced to leave - the vast majority was resettled to the emptied Western Territories. 


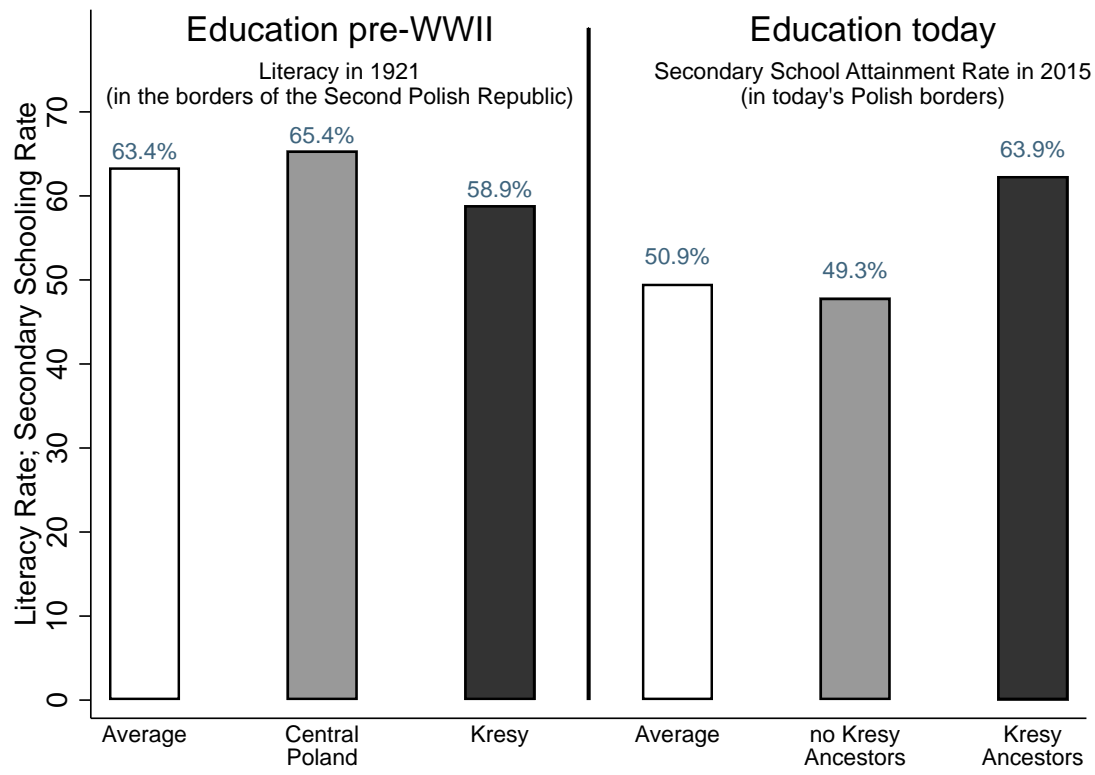

\section{Figure 2: Overview of Historical and Contemporaneous Patterns in Education}

Note: The figure shows the reversal in education for forced migrants and their descendants: People at the origin location of forced migrants (Kresy) had lower education before WWII, while descendants of forced Kresy migrants today have higher educational attainment. The data are from the 1921 Polish Census and the 2015 Diagnoza Survey. For 1921, the figure displays literacy rates of Roman Catholics (i.e., ethnic Poles) in the whole of the Second Polish Republic, which consisted of Kresy (Eastern Borderlands) and Central Poland (CP). Literacy rates were lower in Kresy than in CP. For today's Poland, the figure shows the secondary school attainment rate on average, for people without Kresy ancestors (25,972 respondents), and for people with Kresy ancestors (3,318 respondents). 


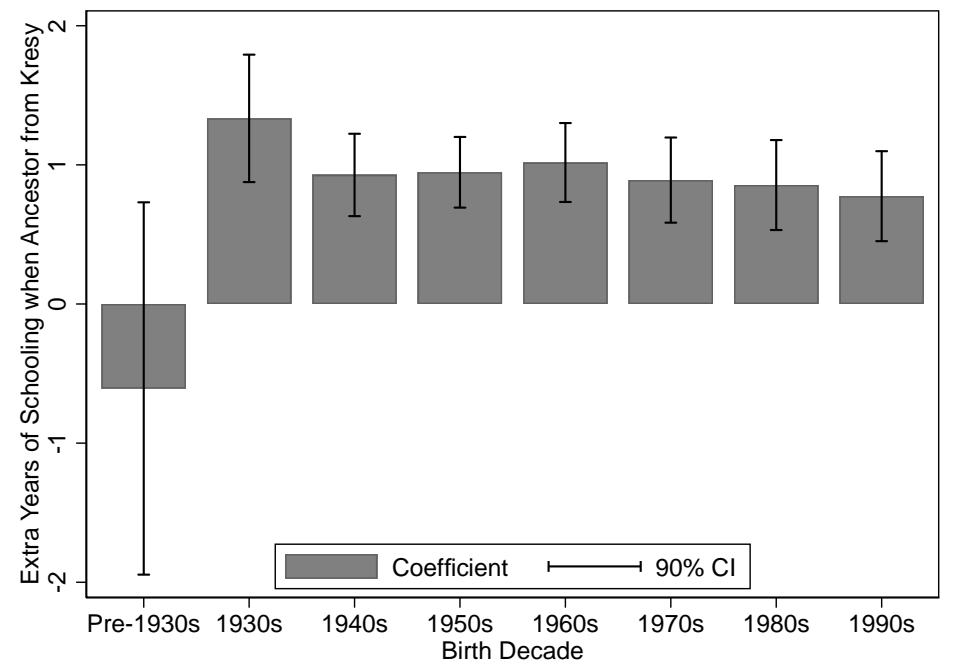

Figure 3: Ancestors from Kresy and Education, by Birth Cohort

Note: The figure visualizes the results of regressing years of education on Kresy ancestry for different birth cohorts. The underlying regressions include our standard controls (see note to Table 2) and respondent county fixed effects. Each bar corresponds to the coefficient on 'Ancestor from Kresy.' The pre-1930 birth cohort was at least 16 years old at the end of WWII and was above schooling age at the time of forced migration. The regressions are run using the Diagnoza sample for 2015 (Table A.3 in the appendix presents regression results for years of schooling as well as completion rates of secondary and higher education). Respondents who were still students by the time of the survey in 2015 are excluded. 

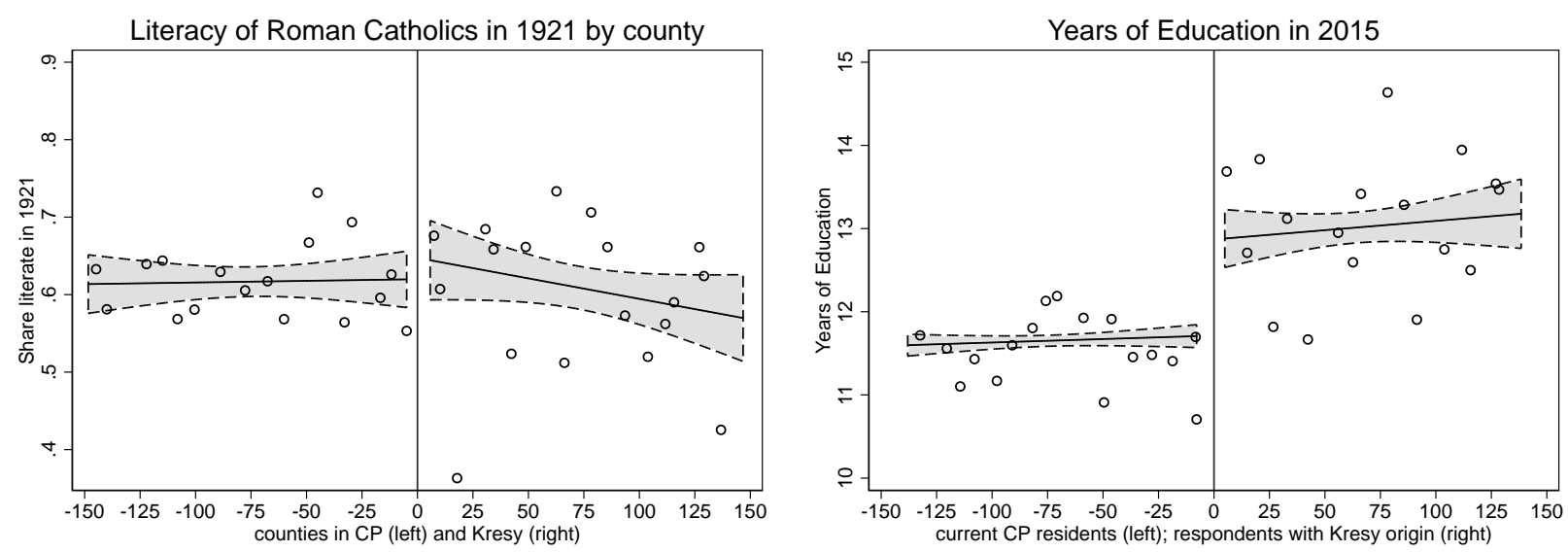

Figure 4: Kresy Border Sample: 1921 Census and Diagnoza Survey

Note: The figure uses only respondents (from the 2015 Diagnoza Survey) with roots in the area of less than $150 \mathrm{~km}$ around the border between Kresy and Central Poland. The left panel shows that there is no difference in literacy in 1921 around the Kresy border. The right panel tracks individuals with roots near the Kresy border by including i) individuals from the Diagnoza Survey with ancestors from Kresy who lived within less than $150 \mathrm{~km}$ to the east of the border, and ii) individuals without Kresy ancestors who live (today) within less than $150 \mathrm{~km}$ to the west of the border. Dots correspond to data aggregated into $8 \mathrm{~km}$ (5 miles) bins for visualization, while the lines are based on all underlying observations, with the shaded area representing $90 \%$ confidence intervals.

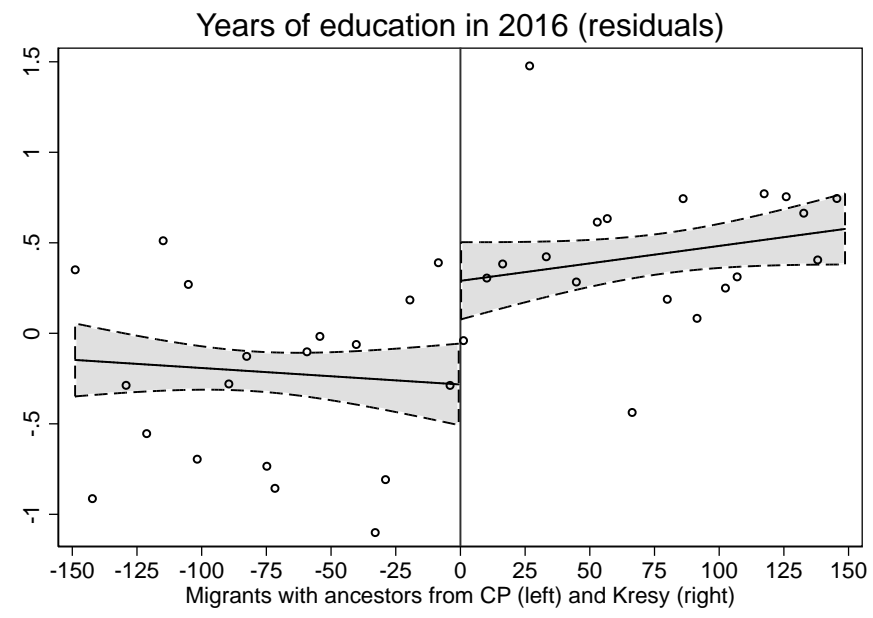

Figure 5: Kresy Border Sample: Ancestry Survey

Note: The figure uses respondents from our Ancestry Survey, i.e., individuals who live in the Western Territories today. Among these, we restrict the sample to people with ancestor roots in the area of less than $150 \mathrm{~km}$ around the border between Kresy and Central Poland. Underlying the figure is an ancestor-level regression, as in specification (2), of years of education on our standard controls (see note to Table 3 ) and on respondents' municipality fixed effects. Dots correspond to residuals from this regression (aggregated into $8 \mathrm{~km}$ (5 miles) bins for visualization), while the lines are based on all underlying observations, with the shaded area representing $90 \%$ confidence intervals. The corresponding regression results are presented in Table A.11 in the appendix. 


\section{TABLES}

Table 1: Overview: Population Census in 1950 (in thousands)

\begin{tabular}{lcc|c}
\hline \hline & $\begin{array}{c}\text { Western Territories } \\
\text { (WT) }\end{array}$ & $\begin{array}{c}\text { Central Poland } \\
(\mathrm{CP})\end{array}$ & $\begin{array}{c}\text { Share of } \\
\text { Western Territories }\end{array}$ \\
\hline & 5,602 & 19,012 & $22.8 \%$ \\
Total population, 1950 & & & \\
& & & \\
\hline By Region of Origin: & 2,785 & 18,355 & $13.2 \%$ \\
Lived in Central Poland in 1939 & $(49.7 \%)$ & $(96.5 \%)$ & \\
& 1,554 & 583 & $72.7 \%$ \\
Lived in USSR (Kresy) in 1939 & $(27.7 \%)$ & $(3.1 \%)$ & \\
& 1,112 & 19 & $98.3 \%$ \\
Lived in Western Territories in 1939 & $(19.9 \%)$ & $(0.1 \%)$ & \\
Lived abroad (not USSR) in 1939 & 152 & 53 & $74.0 \%$ \\
& $(2.7 \%)$ & $(0.3 \%)$ & \\
\hline \hline
\end{tabular}

Notes: The table shows the population of Poland in 1950 by area of residence, as well as origin. Data are from the 1950 Polish census. The three major areas are Kresy (which became part of the Soviet Union after WWII), Central Poland (which had been and remained Polish), and Western Territories (which had been German and became Polish). 
Table 2: Forced Migration from Kresy and Education - Diagnoza Survey Results Dependent variable: Individual-Level education, as indicated in each panel

\begin{tabular}{|c|c|c|c|c|c|c|c|}
\hline Sample: & $\begin{array}{c}(1) \\
\text { All } \\
\text { (no controls) }\end{array}$ & $\begin{array}{l}(2) \\
\text { All }\end{array}$ & $\begin{array}{l}(3) \\
\text { All }\end{array}$ & $\begin{array}{l}\text { (4) } \\
\text { Rural }\end{array}$ & $\begin{array}{l}\text { (5) } \\
\text { Urban }\end{array}$ & $\begin{array}{c}(6) \\
\text { Central } \\
\text { Poland }\end{array}$ & $\begin{array}{c}(7) \\
\text { Western } \\
\text { Territories }\end{array}$ \\
\hline \multicolumn{8}{|c|}{ Panel A. Dep. Var: Years of education } \\
\hline Ancestor from Kresy & $\begin{array}{c}0.969 \\
(0.080)\end{array}$ & $\begin{array}{c}0.819 \\
(0.074)\end{array}$ & $\begin{array}{c}0.801 \\
(0.080)\end{array}$ & $\begin{array}{c}0.670 \\
(0.123)\end{array}$ & $\begin{array}{c}0.900 \\
(0.094)\end{array}$ & $\begin{array}{c}0.933 \\
(0.112)\end{array}$ & $\begin{array}{c}0.705 \\
(0.100)\end{array}$ \\
\hline $\begin{array}{l}\text { Mean Dep. Var. } \\
\text { Observations }\end{array}$ & $\begin{array}{c}11.91 \\
28,341\end{array}$ & $\begin{array}{c}11.91 \\
28,176\end{array}$ & $\begin{array}{c}11.91 \\
28,158\end{array}$ & $\begin{array}{c}11.13 \\
14,111\end{array}$ & $\begin{array}{r}12.70 \\
14,065\end{array}$ & $\begin{array}{c}11.94 \\
21,121\end{array}$ & $\begin{array}{l}11.83 \\
7,055\end{array}$ \\
\hline \multicolumn{8}{|c|}{ Panel B. Dep. Var:: Secondary education dummy } \\
\hline Ancestor from Kresy & $\begin{array}{c}0.145 \\
(0.011)\end{array}$ & $\begin{array}{c}0.112 \\
(0.011)\end{array}$ & $\begin{array}{c}0.110 \\
(0.012)\end{array}$ & $\begin{array}{c}0.105 \\
(0.020)\end{array}$ & $\begin{array}{c}0.118 \\
(0.013)\end{array}$ & $\begin{array}{c}0.112 \\
(0.016)\end{array}$ & $\begin{array}{c}0.109 \\
(0.015)\end{array}$ \\
\hline $\begin{array}{l}\text { Mean Dep. Var. } \\
\text { Observations }\end{array}$ & $\begin{array}{c}0.50 \\
28,343\end{array}$ & $\begin{array}{c}0.50 \\
28,179\end{array}$ & $\begin{array}{c}0.50 \\
28,161\end{array}$ & $\begin{array}{c}0.37 \\
14,120\end{array}$ & $\begin{array}{c}0.62 \\
14,059\end{array}$ & $\begin{array}{c}0.50 \\
21,114\end{array}$ & $\begin{array}{c}0.49 \\
7,065\end{array}$ \\
\hline \multicolumn{8}{|c|}{ Panel C. Dep. Var: Higher education dummy } \\
\hline Ancestor from Kresy & $\begin{array}{c}0.106 \\
(0.010)\end{array}$ & $\begin{array}{c}0.088 \\
(0.010)\end{array}$ & $\begin{array}{c}0.090 \\
(0.011)\end{array}$ & $\begin{array}{c}0.061 \\
(0.016)\end{array}$ & $\begin{array}{c}0.101 \\
(0.014)\end{array}$ & $\begin{array}{c}0.115 \\
(0.016)\end{array}$ & $\begin{array}{c}0.063 \\
(0.013)\end{array}$ \\
\hline $\begin{array}{l}\text { Mean Dep. Var. } \\
\text { Observations }\end{array}$ & $\begin{array}{c}0.20 \\
28,343\end{array}$ & $\begin{array}{c}0.20 \\
28,179\end{array}$ & $\begin{array}{c}0.20 \\
28,161\end{array}$ & $\begin{array}{c}0.12 \\
14,120\end{array}$ & $\begin{array}{c}0.28 \\
14,059\end{array}$ & $\begin{array}{c}0.20 \\
21,114\end{array}$ & $\begin{array}{c}0.20 \\
7,065\end{array}$ \\
\hline $\begin{array}{l}\text { Baseline Controls }{ }^{\ddagger} \\
\text { Respondent county FE } \\
\text { Respondent municipali }\end{array}$ & & $\begin{array}{l}\checkmark \\
\checkmark\end{array}$ & $\begin{array}{l}\checkmark \\
\checkmark\end{array}$ & $\begin{array}{l}\checkmark \\
\checkmark\end{array}$ & $\begin{array}{l}\checkmark \\
\checkmark\end{array}$ & $\begin{array}{l}\checkmark \\
\checkmark\end{array}$ & $\begin{array}{l}\checkmark \\
\checkmark\end{array}$ \\
\hline
\end{tabular}

Notes: The table shows that individuals whose ancestors were expelled from the Kresy territories have significantly higher levels of education today. Regressions are run at the respondent level using data from the 2015 Diagnoza Survey; standard errors are clustered at the household level.

$¥$ Baseline controls include respondents' gender, age and age ${ }^{2}$ interacted with birth-decade dummies, as well as indicators for rural places and urban counties. 
Table 3: Forced Migration from Kresy and Education in Western Territories: Ancestry Survey

Dependent variable: as indicated in table header

\begin{tabular}{|c|c|c|c|c|c|c|c|c|}
\hline & (1) & (2) & (3) & (4) & (5) & (6) & (7) & $(8)$ \\
\hline Dep. Var.: & \multicolumn{6}{|c|}{ Years of Education } & Secondary & Higher \\
\hline Notes on sample: & & & & & rural & urban & & \\
\hline & \multicolumn{8}{|c|}{ Panel A: Respondent-Level Regressions } \\
\hline Ancestor from Kresy & $\begin{array}{c}0.769 \\
(0.107)\end{array}$ & $\begin{array}{c}0.911 \\
(0.099)\end{array}$ & & & & & & \\
\hline Share of Ancestors, Kresy & & & $\begin{array}{c}0.744 \\
(0.125)\end{array}$ & $\begin{array}{c}0.721 \\
(0.131)\end{array}$ & $\begin{array}{c}0.629 \\
(0.239)\end{array}$ & $\begin{array}{c}0.760 \\
(0.150)\end{array}$ & $\begin{array}{c}0.104 \\
(0.020)\end{array}$ & $\begin{array}{c}0.053 \\
(0.017)\end{array}$ \\
\hline Share of Ancestors, WT & & & $\begin{array}{l}-0.980 \\
(0.179)\end{array}$ & $\begin{array}{l}-1.005 \\
(0.194)\end{array}$ & $\begin{array}{c}-0.588 \\
(0.302)\end{array}$ & $\begin{array}{c}-1.240 \\
(0.241)\end{array}$ & $\begin{array}{l}-0.169 \\
(0.029)\end{array}$ & $\begin{array}{c}-0.128 \\
(0.023)\end{array}$ \\
\hline Share of Ancestors, abroad & & & $\begin{array}{c}-0.608 \\
(0.623)\end{array}$ & $\begin{array}{c}-0.493 \\
(0.596)\end{array}$ & $\begin{array}{c}-1.917 \\
(1.397)\end{array}$ & $\begin{array}{l}-0.261 \\
(0.679)\end{array}$ & $\begin{array}{c}-0.004 \\
(0.098)\end{array}$ & $\begin{array}{c}-0.038 \\
(0.090)\end{array}$ \\
\hline Share of Ancestors, rural & & & $\begin{array}{c}-0.847 \\
(0.135)\end{array}$ & $\begin{array}{c}-0.849 \\
(0.138)\end{array}$ & $\begin{array}{c}-0.995 \\
(0.330)\end{array}$ & $\begin{array}{c}-0.793 \\
(0.150)\end{array}$ & $\begin{array}{c}-0.107 \\
(0.021)\end{array}$ & $\begin{array}{c}-0.072 \\
(0.019)\end{array}$ \\
\hline $\begin{array}{l}\text { Baseline Controls }^{\ddagger} \\
\text { Respondent County FE } \\
\text { Respondent Municipality FE }\end{array}$ & & $\begin{array}{l}\checkmark \\
\checkmark\end{array}$ & $\begin{array}{l}\checkmark \\
\checkmark\end{array}$ & $\begin{array}{l}\checkmark \\
\checkmark\end{array}$ & $\begin{array}{l}\checkmark \\
\checkmark\end{array}$ & $\begin{array}{l}\checkmark \\
\checkmark\end{array}$ & $\begin{array}{l}\checkmark \\
\checkmark\end{array}$ & $\begin{array}{l}\checkmark \\
\checkmark\end{array}$ \\
\hline Mean Dep. Var. & 12.70 & 12.70 & 12.71 & 12.71 & 11.55 & 13.22 & 0.52 & 0.23 \\
\hline $\mathrm{R}^{2}$ & 0.01 & 0.27 & 0.28 & 0.36 & 0.32 & 0.25 & 0.20 & 0.20 \\
\hline \multirow[t]{2}{*}{ Observations } & 3,716 & 3,716 & 3,668 & 3,668 & 1,110 & 2,558 & 3,668 & 3,668 \\
\hline & \multicolumn{8}{|c|}{ Panel B: Ancestor-Level Regressions } \\
\hline Ancestor from Kresy & $\begin{array}{c}0.641 \\
(0.096)\end{array}$ & $\begin{array}{c}0.648 \\
(0.088)\end{array}$ & $\begin{array}{c}0.497 \\
(0.092)\end{array}$ & $\begin{array}{c}0.456 \\
(0.090)\end{array}$ & $\begin{array}{c}0.342 \\
(0.174)\end{array}$ & $\begin{array}{c}0.526 \\
(0.107)\end{array}$ & $\begin{array}{c}0.071 \\
(0.015)\end{array}$ & $\begin{array}{c}0.045 \\
(0.014)\end{array}$ \\
\hline Ancestor from WT & & & $\begin{array}{c}-0.898 \\
(0.136)\end{array}$ & $\begin{array}{c}-0.857 \\
(0.133)\end{array}$ & $\begin{array}{c}-0.711 \\
(0.228)\end{array}$ & $\begin{array}{c}-0.971 \\
(0.175)\end{array}$ & $\begin{array}{c}-0.154 \\
(0.024)\end{array}$ & $\begin{array}{c}-0.126 \\
(0.020)\end{array}$ \\
\hline Ancestor from abroad & & & $\begin{array}{c}1.017 \\
(0.976)\end{array}$ & $\begin{array}{c}1.293 \\
(0.859)\end{array}$ & $\begin{array}{c}-0.040 \\
(0.711)\end{array}$ & $\begin{array}{c}2.056 \\
(1.182)\end{array}$ & $\begin{array}{c}0.152 \\
(0.137)\end{array}$ & $\begin{array}{c}0.107 \\
(0.179)\end{array}$ \\
\hline Ancestor from rural area & & & $\begin{array}{c}-0.505 \\
(0.098)\end{array}$ & $\begin{array}{c}-0.517 \\
(0.093)\end{array}$ & $\begin{array}{c}-0.692 \\
(0.227)\end{array}$ & $\begin{array}{c}-0.447 \\
(0.106)\end{array}$ & $\begin{array}{c}-0.071 \\
(0.016)\end{array}$ & $\begin{array}{l}-0.045 \\
(0.015)\end{array}$ \\
\hline Grandparent & $\begin{array}{c}1.438 \\
(0.119)\end{array}$ & $\begin{array}{c}0.331 \\
(0.163)\end{array}$ & $\begin{array}{c}0.394 \\
(0.162)\end{array}$ & $\begin{array}{c}0.351 \\
(0.163)\end{array}$ & $\begin{array}{c}0.602 \\
(0.284)\end{array}$ & $\begin{array}{c}0.348 \\
(0.198)\end{array}$ & $\begin{array}{c}0.029 \\
(0.026)\end{array}$ & $\begin{array}{c}0.039 \\
(0.021)\end{array}$ \\
\hline Great-grandparent & $\begin{array}{c}2.508 \\
(0.159)\end{array}$ & $\begin{array}{c}0.911 \\
(0.229)\end{array}$ & $\begin{array}{c}1.023 \\
(0.229)\end{array}$ & $\begin{array}{c}0.873 \\
(0.231)\end{array}$ & $\begin{array}{c}0.937 \\
(0.401)\end{array}$ & $\begin{array}{c}1.021 \\
(0.276)\end{array}$ & $\begin{array}{c}0.165 \\
(0.038)\end{array}$ & $\begin{array}{c}0.109 \\
(0.035)\end{array}$ \\
\hline $\begin{array}{l}\text { Baseline Controls }^{\ddagger} \\
\text { Respondent County FE } \\
\text { Respondent Municipality FE }\end{array}$ & & $\begin{array}{l}\checkmark \\
\checkmark\end{array}$ & $\begin{array}{l}\checkmark \\
\checkmark\end{array}$ & $\checkmark$ & $\begin{array}{l}\checkmark \\
\checkmark\end{array}$ & $\begin{array}{l}\checkmark \\
\checkmark\end{array}$ & $\begin{array}{l}\checkmark \\
\checkmark\end{array}$ & $\begin{array}{l}\checkmark \\
\checkmark\end{array}$ \\
\hline Mean Dep. Var. & 13.03 & 13.03 & 13.04 & 13.04 & 11.95 & 13.54 & 0.55 & 0.26 \\
\hline $\mathrm{R}^{2}$ & 0.07 & 0.28 & 0.29 & 0.38 & 0.32 & 0.27 & 0.22 & 0.23 \\
\hline Observations & 11,928 & 11,928 & 11,548 & 11,548 & 3,617 & 7,931 & 11,548 & 11,548 \\
\hline
\end{tabular}

Notes: The table uses data from our 2016 Ancestry Survey in the Western Territories, showing that the share of ancestors from Kresy in a respondent's family tree is associated with higher levels of education. Regressions are run at the respondent level in Panel A, and at the ancestor level in Panel B. Robust standard errors (in Panel B clustered at the level of respondents corresponding to each ancestor) indicated in parentheses.

$\ddagger$ Controls include respondents’ gender, age and age ${ }^{2}$ intgracted with birth-decade dummies, as well as indicators for respondents living in rural places and urban counties. Excluded category in columns (3) to (7) is ancestors from Central Poland. 
Table 4: Main Results for Kresy Migrants from Rural vs. Urban Areas, and from Ukraine Only

Dependent variable: Years of education in 2016, at the respondent level

\begin{tabular}{|c|c|c|c|c|c|c|c|c|}
\hline \multirow{3}{*}{$\begin{array}{l}\text { "Ancestors from Kresy" includes: } \\
\text { Notes on sample: }\end{array}$} & (1) & (2) & (3) & (4) & (5) & (6) & (7) & $(8)$ \\
\hline & \multicolumn{4}{|c|}{ All Kresy Ancestors } & \multicolumn{4}{|c|}{ Only Kresy Ancestors from Ukraine } \\
\hline & all & $\begin{array}{c}\text { Ancesto } \\
\text { urban }\end{array}$ & $\begin{array}{l}\text { location: } \\
\text { rural }\end{array}$ & $\begin{array}{l}\text { Anc. and Resp. } \\
\text { all urban }\end{array}$ & all & $\begin{array}{c}\text { Ancesto } \\
\text { urban }\end{array}$ & $\begin{array}{l}\text { location: } \\
\text { rural }\end{array}$ & $\begin{array}{l}\text { Anc. and Resp. } \\
\text { all urban }\end{array}$ \\
\hline Ancestor from Kresy & $\begin{array}{c}0.497 \\
(0.092)\end{array}$ & $\begin{array}{c}0.637 \\
(0.160)\end{array}$ & $\begin{array}{c}0.429 \\
(0.109)\end{array}$ & $\begin{array}{c}0.559 \\
(0.172)\end{array}$ & $\begin{array}{c}0.440 \\
(0.110)\end{array}$ & $\begin{array}{c}0.588 \\
(0.182)\end{array}$ & $\begin{array}{c}0.345 \\
(0.131)\end{array}$ & $\begin{array}{c}0.449 \\
(0.197)\end{array}$ \\
\hline $\begin{array}{l}\text { Baseline Controls }^{\ddagger} \\
\text { Ancestor Controls }^{\dagger} \\
\text { Respondent County FE }\end{array}$ & $\begin{array}{l}\checkmark \\
\checkmark \\
\checkmark\end{array}$ & $\begin{array}{l}\checkmark \\
\checkmark \\
\checkmark\end{array}$ & $\begin{array}{l}\checkmark \\
\checkmark \\
\checkmark\end{array}$ & $\begin{array}{l}\checkmark \\
\checkmark \\
\checkmark\end{array}$ & $\begin{array}{l}\checkmark \\
\checkmark \\
\checkmark\end{array}$ & $\begin{array}{l}\checkmark \\
\checkmark \\
\checkmark\end{array}$ & $\begin{array}{l}\checkmark \\
\checkmark \\
\checkmark\end{array}$ & $\begin{array}{l}\checkmark \\
\checkmark \\
\checkmark\end{array}$ \\
\hline $\begin{array}{l}\text { Mean Dep. Var. } \\
\mathrm{R}^{2} \\
\text { Observations }\end{array}$ & $\begin{array}{c}13.04 \\
0.29 \\
11,548\end{array}$ & $\begin{array}{c}13.64 \\
0.31 \\
2,950\end{array}$ & $\begin{array}{c}12.84 \\
0.33 \\
8,598\end{array}$ & $\begin{array}{c}13.87 \\
0.31 \\
2,417\end{array}$ & $\begin{array}{c}12.98 \\
0.29 \\
10,237\end{array}$ & $\begin{array}{c}13.52 \\
0.32 \\
2,568\end{array}$ & $\begin{array}{c}12.80 \\
0.34 \\
7,669\end{array}$ & $\begin{array}{c}13.73 \\
0.34 \\
2,080\end{array}$ \\
\hline
\end{tabular}

Notes: The table uses data from our 2016 Ancestry Survey in the Western Territories, showing that the coefficient on Kresy ancestors is, if anything, larger for ancestors from urban areas (where expulsion from Kresy was complete), and that the coefficient is robust to using only the Ukrainian part of Kresy, where expulsions were also nearly complete, leaving essentially no scope for selection at the origin locations. Regressions are run at the ancestor level; standard errors clustered by individual respondents.

$\ddagger$ Baseline controls include respondents’ gender, age and age ${ }^{2}$ interacted with birth-decade dummies, and indicators for respondents living in rural locations and urban counties.

$\dagger$ Ancestor controls include indicators for ancestors from Western Territories, from abroad, and from rural areas, as well as indicators for the ancestor generation. Excluded category is ancestors from Central Poland. 


\section{Table 5: Attitudes towards Education and Material Possessions}

Dependent variable: Individual-level outcomes, as indicated in table

\begin{tabular}{|c|c|c|c|c|c|c|c|c|}
\hline & \multirow{3}{*}{\multicolumn{2}{|c|}{$\begin{array}{l}\text { (1) } \\
\text { High aspiration for edu- } \\
\text { cation of own children }\end{array}$}} & (3) & (4) & (5) & (6) & (7) & (8) \\
\hline & & & \multicolumn{4}{|c|}{ Main condition for success in life? } & \multirow{2}{*}{\multicolumn{2}{|c|}{$\begin{array}{l}\% \text { Assets not owned } \\
\text { for non-financial reasons }\end{array}$}} \\
\hline & & & \multicolumn{2}{|c|}{ Material goods } & \multicolumn{2}{|c|}{ Freedom } & & \\
\hline Ancestor from Kresy & $\begin{array}{c}0.080 \\
(0.032)\end{array}$ & $\begin{array}{c}0.067 \\
(0.032)\end{array}$ & $\begin{array}{l}-0.076 \\
(0.013)\end{array}$ & $\begin{array}{l}-0.063 \\
(0.013)\end{array}$ & $\begin{array}{c}0.017 \\
(0.006)\end{array}$ & $\begin{array}{c}0.016 \\
(0.006)\end{array}$ & $\begin{array}{c}0.042 \\
(0.009)\end{array}$ & $\begin{array}{c}0.034 \\
(0.009)\end{array}$ \\
\hline Years of education & & $\begin{array}{c}0.047 \\
(0.004)\end{array}$ & & $\begin{array}{l}-0.015 \\
(0.001)\end{array}$ & & $\begin{array}{c}0.001 \\
(0.001)\end{array}$ & & $\begin{array}{c}0.011 \\
(0.001)\end{array}$ \\
\hline Baseline Controls ${ }^{\ddagger}$ & $\checkmark$ & $\checkmark$ & $\checkmark$ & $\checkmark$ & $\checkmark$ & $\checkmark$ & $\checkmark$ & $\checkmark$ \\
\hline Respondent County FE & $\checkmark$ & $\checkmark$ & $\checkmark$ & $\checkmark$ & $\checkmark$ & $\checkmark$ & $\checkmark$ & $\checkmark$ \\
\hline Mean Dep. Var. & 0.59 & 0.59 & 0.56 & 0.56 & 0.05 & 0.05 & 0.69 & 0.69 \\
\hline R-squared & 0.26 & 0.29 & 0.11 & 0.12 & 0.05 & 0.05 & 0.18 & 0.19 \\
\hline Observations & 3,800 & 3,800 & 22,050 & 22,050 & 21,586 & 21,586 & 28,019 & 28,019 \\
\hline
\end{tabular}

Notes: The table shows that descendants of Kresy migrants have stronger preferences for the education of their children, value material goods less, value freedom more, and chose to own fewer assets (even if they could afford them). Regressions are run at the respondent level using data from the 2015 Diagnoza Survey; standard errors are clustered at the household level.

$\ddagger$ Baseline Controls include respondents’ gender, age and age ${ }^{2}$ interacted with birth-decade dummies, as well as indicators for rural places and urban counties.

\# Diagnoza asks respondents to rank their aspiration for education of their children on a scale from 1 to 5 . The dependent variable is an indicator for the highest category. Note that the sample is smaller because this question is not answered when children have already finished their education.

${ }^{\dagger}$ Diagnoza asks about the possession of 20 different assets (e.g., apartment, vacation house, garden land plot, ebook reader, home theatre, boat). For those assets not possessed, respondents are asked if this is for financial reasons. The dependent variable in columns 7-8 is the number assets not owned for non-financial reasons, divided by the number of all non-possessed assets. 
Table 6: Other Potential Channels: Congestion, Returns to Schooling, Out-Migration, Differential Fertility

Dep. Var.: as indicated in table header. Data from Diagnoza.

\begin{tabular}{|c|c|c|c|c|c|c|c|}
\hline Analysis: & $\begin{array}{c}(1) \\
\text { Congestion? }\end{array}$ & \multicolumn{2}{|c|}{ Return to Schooling? } & \multicolumn{2}{|c|}{ Out-Migration? } & \multicolumn{2}{|c|}{ Fertility? } \\
\hline Dep. Var.: & $\begin{array}{c}\text { Years of } \\
\text { education }\end{array}$ & \multicolumn{2}{|c|}{$\log (\mathrm{HH}$ income $)$} & \multicolumn{2}{|c|}{ Intend to go abroad } & \multicolumn{2}{|c|}{$\begin{array}{c}\text { Share of } \\
\text { Children in } \mathrm{HH} \\
\end{array}$} \\
\hline Sample & WT & all & WT & all & all & all & $\#$ children $\geq 1$ \\
\hline Ancestor from Kresy & $\begin{array}{c}0.732 \\
(0.089)\end{array}$ & $\begin{array}{c}0.080 \\
(0.040)\end{array}$ & $\begin{array}{c}0.037 \\
(0.047)\end{array}$ & $\begin{array}{l}-0.001 \\
(0.006)\end{array}$ & $\begin{array}{c}0.007 \\
(0.010)\end{array}$ & $\begin{array}{l}-0.004 \\
(0.005)\end{array}$ & $\begin{array}{c}0.004 \\
(0.008)\end{array}$ \\
\hline Sh Autochthons (std) $\times$ Kresy & $\begin{array}{c}0.137 \\
(0.092)\end{array}$ & & & & & & \\
\hline Years education (std) & & $\begin{array}{c}0.179 \\
(0.010)\end{array}$ & $\begin{array}{c}0.210 \\
(0.021)\end{array}$ & & $\begin{array}{c}0.002 \\
(0.003)\end{array}$ & & \\
\hline Years edu $($ std $) \times$ Kresy & & $\begin{array}{l}-0.039 \\
(0.025)\end{array}$ & $\begin{array}{c}0.003 \\
(0.033)\end{array}$ & & $\begin{array}{l}-0.008 \\
(0.008)\end{array}$ & & \\
\hline Baseline Controls ${ }^{\ddagger}$ & $\checkmark$ & $\checkmark$ & $\checkmark$ & $\checkmark$ & $\checkmark$ & $\checkmark$ & $\checkmark$ \\
\hline Respondent County FE & $\checkmark$ & $\checkmark$ & $\checkmark$ & $\checkmark$ & $\checkmark$ & $\checkmark$ & $\checkmark$ \\
\hline Mean Dep. Var. & 11.83 & 8.45 & 8.40 & 0.06 & 0.09 & 0.11 & 0.32 \\
\hline R-squared & 0.27 & 0.22 & 0.21 & 0.06 & 0.07 & 0.19 & 0.23 \\
\hline Observations & 7,055 & 18,262 & 4,422 & 22,090 & 14,026 & 28,122 & 9,184 \\
\hline
\end{tabular}

Notes: The table examines four alternative mechanisms that may explain the education advantage of people with Kresy ancestors: congestion due to the presence of autochthons (column 1); differential returns to education (columns 2-3); differential out-migration (columns 4-5); and differential fertility (columns 6-7). None of these appear to confound the coefficient on Kresy. Regressions are run at the level of respondents in Diagnoza; standard errors clustered by country. $\mathrm{WT}=$ Western Territories.

$\ddagger$ Controls include respondents’ gender, age and age ${ }^{2}$ interacted with birth-decade dummies, as well as indicators for rural places and urban counties. 